\title{
Using a WRF simulation to examine regions where convection impacts the Asian summer monsoon anticyclone
}

\author{
N. K. Heath and H. E. Fuelberg \\ Department of Earth, Ocean and Atmospheric Science, Florida State University, Tallahassee, FL 32306-4520, USA
}

Correspondence to: N. K. Heath (nkh09@my.fsu.edu)

Received: 11 July 2013 - Published in Atmos. Chem. Phys. Discuss.: 24 September 2013

Revised: 6 December 2013 - Accepted: 19 January 2014 - Published: 21 February 2014

\begin{abstract}
The Asian summer monsoon is a prominent feature of the global circulation that is associated with an upperlevel anticyclone (ULAC) that stands out vividly in satellite observations of trace gases. The ULAC also is an important region of troposphere-to-stratosphere transport. We ran the Weather Research and Forecasting (WRF) model at convective-permitting scales ( $4 \mathrm{~km}$ grid spacing) between 10 and 20 August 2012 to understand the role of convection in rapidly transporting boundary layer air into the ULAC. Such high-resolution modeling of the Asian ULAC previously has not been documented in the literature. Comparison of our WRF simulation with reanalysis and satellite observations showed that WRF simulated the atmosphere sufficiently well to be used to study convective transport into the ULAC. A back-trajectory analysis based on hourly WRF output showed that $>90 \%$ of convectively influenced parcels reaching the ULAC came from the Tibetan Plateau (TP) and the southern slope (SS) of the Himalayas. A distinct diurnal cycle is seen in the convective trajectories, with a majority of them crossing the boundary layer between 1600 and 2300 local solar time. This finding highlights the role of "everyday" diurnal convection in transporting boundary layer air into the ULAC.

WRF output at 15 min intervals was produced for $16 \mathrm{Au}-$ gust to examine the convection in greater detail. This hightemporal output revealed that the weakest convection in the study area occurred over the TP. However, because the TP is at $3000-5000 \mathrm{~m}$ a.m.s.l., its convection does not have to be as strong to reach the ULAC as in lower altitude regions. In addition, because the TP's elevated heat source is a major cause of the ULAC, we propose that convection over the TP and the neighboring SS is ideally situated geographically to impact the ULAC.
\end{abstract}

The vertical mass flux of water vapor into the ULAC also was calculated. Results show that the TP and SS regions dominate other Asian regions in transporting moisture vertically into the ULAC. Because convection reaching the ULAC is more widespread over the TP than nearby, we propose that the abundant convection partially explains the TP's dominant water vapor fluxes. In addition, greater outgoing longwave radiation reaches the upper levels of the TP due to its elevated terrain. This creates a warmer ambient upper-level environment, allowing parcels with greater saturation mixing ratios to enter the ULAC. Lakes in the Tibetan Plateau are shown to provide favorable conditions for deep convection during the night.

\section{Introduction and background}

Southeast Asia is a region of rapidly increasing population and emissions (Zhang et al., 2009). Deep convection associated with the Asian summer monsoon (ASM) can transport surface-based emissions into the upper troposphere/lower stratosphere (UTLS; e.g., Li et al., 2005; Randel et al., 2010). The upper-level anticyclone (ULAC) associated with the ASM appears to provide a pathway for troposphere-tostratosphere transport (TST; Gettelman et al., 2004; Park et al., 2007), making its composition important to UTLS chemistry. However, the exact role that deep convection in the ASM plays in controlling the composition of the ULAC is still debated. Previous studies of the region (e.g., Fu et al., 2006; Park et al., 2007, 2009; James et al., 2008; Chen et al., 2012) have reached varying, even contradictory, conclusions. These previous studies were limited by coarse-resolution 


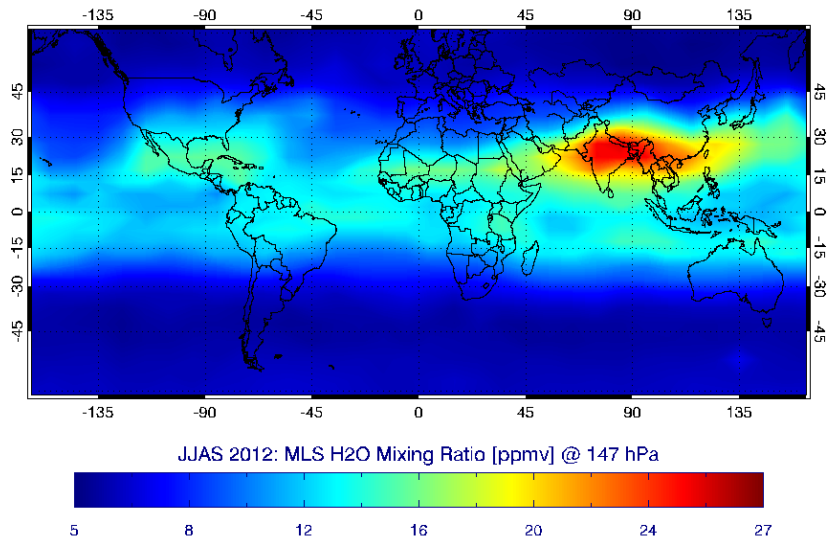

Fig. 1. Aura MLS water vapor mixing ratio (ppmv) at $147 \mathrm{hPa}$ averaged during June, July, August, and September 2012. The MLS data were binned into $5^{\circ}$ latitude by $10^{\circ}$ longitude cells similar to the method of Park et al. (2007).

models and by observations that were limited in both time and space.

The impact of convective detrainment on the composition of the tropical UTLS has been discussed in many previous studies (e.g., Fueglistaler et al., 2009, especially Sects. 3.4 and 3.7, and references therein). Bergman et al. (2012) suggested three pathways that convectively influenced air can take: (1) air is detrained below the tropopause and recirculated back into the boundary layer; (2) air is detrained above the tropopause, but then advected into a region of negative heating rates, thus leading to descent; or (3) air is detrained above the tropopause, advected into regions of positive heating, and subsequently lofted into the lower stratosphere (see their Fig. 1 for a schematic of these pathways). The relative frequency of these pathways has not been determined.

A common approach for diagnosing the pathways by which air travels to the UTLS is to perform back-trajectory analyses on a global scale (e.g., Bonazzola and Haynes, 2004; Fueglistaler et al., 2004; James et al., 2008; Tzella and Legras, 2011; Bergman et al., 2012) to determine the sources of air comprising the tropical tropopause layer (TTL; Gettelman and Forster, 2002; Fueglistaler et al., 2009). This method allows the inference of quantitative and qualitative information about transport into the TTL. However, the use of global models in these previous studies limited their ability to make conclusive statements about the impacts of convection. This is partially due to the coarse resolution at which the models were run, greatly limiting their ability to resolve convective-scale motions. For example, Bonazzola and Haynes (2004) used 3-dimensional winds from the European Center for Medium-range Weather Forecasting (ECMWF) model at T106 resolution $\left(\sim 1.125^{\circ} \times 1.125^{\circ}\right.$ grid spacing $)$ to calculate back trajectories from regions of TST. Although their results implied that convective transport sometimes pen- etrated the cold point tropopause, they could not be confident that the results were realistic.

Other studies (e.g., James et al., 2008; Tzella and Legras, 2011; Bergman et al., 2012) have used horizontal winds together with radiative forcing concepts to account for diabatic effects (and thus vertical motion) instead of using threedimensional wind data. Briefly stated, cirrus clouds in the main convective outflow region $(\sim 12-14 \mathrm{~km})$ absorb outgoing longwave radiation, creating mesoscale regions of positive buoyancy which lead to upward transport to the UTLS at altitudes of $\sim 16-17 \mathrm{~km}$ (Corti et al., 2005, 2006; specifically Fig. 5 from Corti et al., 2006). Results using this "cirruslofting" parameterization indicated that convection has little influence on the global-scale composition of the UTLS.

The abovementioned studies examined general aspects of how convection impacts the UTLS. Numerous studies also have focused on the influence of the ASM on the ULAC. Dunkerton (1995) showed that, from a climatological perspective, the anticyclonic circulation associated with the ASM extends well into the lower stratosphere (up to $\sim 70 \mathrm{hPa}$ ). The ASM ULAC also has been shown to be a region where tropospheric tracers undergo isentropic TST (Chen, 1995). Observations of the UTLS within the ULAC vividly reveal enhanced mixing ratios of carbon monoxide (CO; $\mathrm{Li}$ et al., 2005) and water vapor $\left(\mathrm{H}_{2} \mathrm{O}\right.$; Randel and Park, 2006; James et al., 2008) along with decreased mixing ratios of ozone $\left(\mathrm{O}_{3}\right.$; Park et al., 2007, 2008). For example, Fig. 1 shows the water vapor mixing ratio from the Microwave Limb Sounder (MLS) at $\sim 146 \mathrm{hPa}$ during summer 2012 . The distinct $\mathrm{H}_{2} \mathrm{O}$ maximum associated with the ASM ULAC is a major global feature. Observations have revealed that, once pollution enters the ULAC, it can become "trapped" within the anticyclonic circulation (Randel and Park, 2006; Park et al., 2008). Gettelman et al. (2004) showed that the ASM circulation might provide $75 \%$ of the total $\mathrm{H}_{2} \mathrm{O}$ flux into the tropical lower stratosphere during the summer months, again indicating its importance to TST. Finally, air in the ULAC is periodically subjected to long-range transport across the Pacific and can impact the air quality of the western United States (Jiang et al., 2007). For these reasons, the ULAC is an important feature when considering UTLS chemistry on both local and global scales.

Randel and Park (2006) showed that anomalous mixing ratios of $\mathrm{H}_{2} \mathrm{O}$ and $\mathrm{O}_{3}$ in the UTLS of the ASM are correlated with monsoonal convective events, but with a 5-day lag. Other observations revealed that $\mathrm{H}_{2} \mathrm{O}$ at $216 \mathrm{hPa}$ is highly correlated with convection, but is displaced both temporally and horizontally at $100 \mathrm{hPa}$ (Park et al., 2007). James et al. (2008) used a back-trajectory analysis to hypothesize that the $\mathrm{H}_{2} \mathrm{O}$ maximum in the ULAC at $100 \mathrm{hPa}$ is the result of large-scale transport across the TTL, and that convection does not immediately impact the composition of the ULAC. However, modeling studies have indicated that deep convection over India and southeast Asia can account for 30\% of the $\mathrm{CO}$ at $100 \mathrm{hPa}$ (Park et al., 2009). 
The Tibetan Plateau has been described as a favorable region for convection to bypass the cold point tropopause, allowing warmer, moister parcels to enter the lower stratosphere (Fu et al., 2006). Chen et al. (2012) used National Centers for Environmental Prediction/Global Forecast System (NCEP/GFS) data with $1^{\circ} \times 1^{\circ}$ grid spacing to diagnose regions where boundary layer air impacts the lower stratosphere during the ASM. Their results, contrary to those of Fu et al. (2006), suggested that convection over the Tibetan Plateau plays a minor role compared to convection over the South China Sea and Bay of Bengal. To summarize, there currently is no consensus on the effects of deep convection on the chemical composition of the ULAC. In particular, no agreement has been reached on the importance of different geographical regions in transporting boundary layer air into the ULAC.

A common limitation of previous research examining convection in the ASM has been the uncertainty in the vertical velocity fields from the meteorological models being used. Deep convection occurs on the scale of a few kilometers for isolated cells, and hundreds of kilometers for organized convection (e.g., mesoscale convective systems; Markowski and Richardson, 2010). Furthermore, mesoscale orographic features often trigger convection in the ASM region. For example, nighttime downslope flow associated with radiative cooling can collide with onshore low-level monsoon flow to initiate deep convection over the southern slope (SS) of the Himalayas (e.g., Luo et al., 2010; Romatschke et al., 2010). Previous studies examining the impacts of convection on the ULAC (e.g., Park et al., 2009; Chen et al., 2012) could not explicitly resolve these mesoscale convective events and therefore had to rely on convective parameterizations. Parameterizations vary in their assumptions, "trigger" mechanisms, and closure techniques (e.g., Kain, 2003 vs. Grell and Devenyi, 2002). Therefore, differing model results sometimes can be attributed to which parameterization is chosen (e.g., Taylor, 2011). To fully understand the details of deep convective transport into the ULAC, convection must be explicitly resolved, and, to our knowledge, this has not been documented previously.

The goal of this paper is to simulate ASM deep convection at a fine-scale resolution that previously has not been utilized, and then use the high-resolution output to study the impacts of rapid vertical transport due to convection on the ULAC. We seek to identify the geographic regions whose convection reaches the ULAC, and provide physical and dynamical reasoning for why these regions are important. Section 2 describes our high-resolution, convective-permitting ( $4 \mathrm{~km}$ grid spacing; Lackmann, 2010) Weather Research and Forecasting (WRF; Skamarock et al., 2008) simulations, including the data used to drive the model and the simulation period that was chosen. That section also describes the HYbrid Single-Particle Lagrangian Integrated Trajectory (HYSPLIT; Draxler and Hess, 1998) model that was used for trajectory analyses, along with the observational data that were used to complement our WRF simulation. Section 3 uses the WRF simulation, results from HYSPLIT, and observations to describe convective transport into the ULAC, diagnose regions where convection impacts the ULAC most frequently, and provide physical insight into why certain geographical regions are more important than others when considering convective impacts on the ULAC. Section 4 presents a summary and conclusions.

\section{Data and methods}

\subsection{WRF model description}

We used WRF Version 3.4.1 (Skamarock et al., 2008) to make simulations over three domains (Fig. 2). From outer to inner, the domains used 36,12 , and $4 \mathrm{~km}$ grid spacing, respectively. Initial and boundary conditions came from NCEP/GFS final analyses (FNL) with $1^{\circ} \times 1^{\circ}$ grid spacing. Temperature, horizontal winds, and moisture in the outer two domains (d01 and d02) were nudged to the GFS analyses every $6 \mathrm{~h}$. This nudging was performed only at levels above the boundary layer and was used to keep large-scale features consistent with observations. Nudging was not employed in the innermost domain (d03). However, because d03 receives its boundary conditions from $\mathrm{d} 02$, the nudging in $\mathrm{d} 02$ does influence d03. All analyses presented in this paper are from d03. We analyzed only d03 because of our focus on convective processes. Klich and Fuelberg (2014) performed an extensive analysis on the role of horizontal grid spacing on vertical transport. Their results highlighted the importance of using convective-permitting scales (1-5 km grid spacing) when simulating deep convection. All domains used here had 70 terrain-following vertical sigma levels that spanned the surface to $10 \mathrm{hPa}$. In the lower troposphere, the vertical grid spacing was $\sim 75-150 \mathrm{~m}$. In the mid- to upper troposphere and lower stratosphere, the vertical grid spacing was $\sim 380 \mathrm{~m}$. Diffusive damping was applied in the topmost $5 \mathrm{~km}$ of the model to prevent gravity waves from reflecting off the upper boundary of $10 \mathrm{hPa}$. Meteorological variables were integrated forward in time using Runge-Kutta 3rd-order time integration. All moisture variables and other scalars were advected using a positive-definite scheme to ensure mass conservation.

The outer two domains of the simulation used an updated version of the Grell-Devenyi (Grell and Devenyi, 2002) cumulus parameterization scheme. The innermost domain with $4 \mathrm{~km}$ grid spacing did not employ convective parameterization; i.e., convection was explicitly resolved. We use the phrase "explicit resolution" loosely because, even at $4 \mathrm{~km}$ grid spacing, the model is unable to resolve all convective motions (e.g., individual cumulus clouds). Furthermore, using explicit resolution at $4 \mathrm{~km}$ grid spacing will inherently limit the minimum convective updraft width to this scale. For example, an updraft in nature having a width of $1 \mathrm{~km}$ 


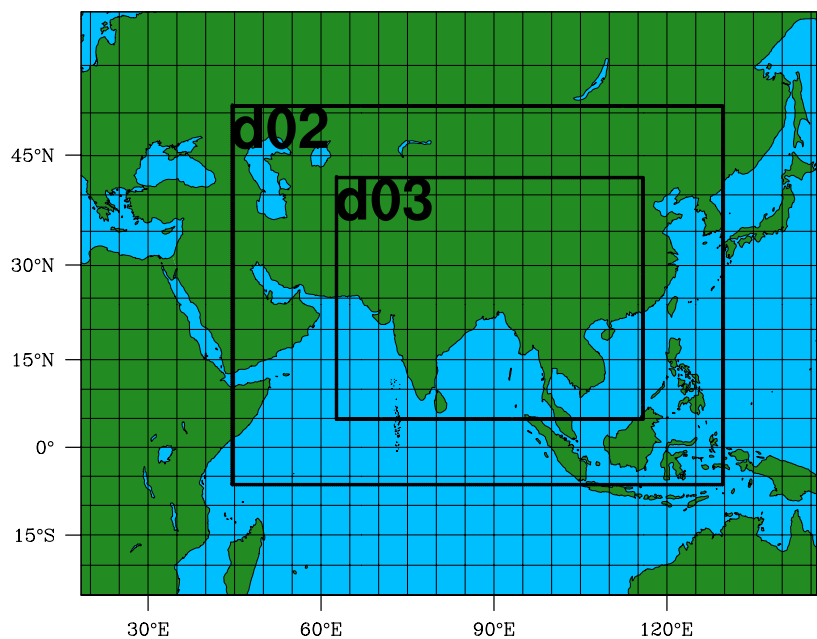

Fig. 2. The three domains used in the WRF simulation. The outer domain has $36 \mathrm{~km}$ grid spacing, domain 2 (d02) $12 \mathrm{~km}$, and domain 3 (d03) $4 \mathrm{~km}$. All analyses presented in this paper are based on results from domain 3 .

will be enlarged in the WRF simulation, which could lead to excessive latent heating and updraft strengths. This caveat should be considered when interpreting the results that follow. Nonetheless, previous studies (e.g., Done et al., 2004; Weisman et al., 2008; Kain et al., 2008) have shown that models at $4 \mathrm{~km}$ grid spacing can provide useful and realistic information about convective storms.

Cloud microphysics were parameterized using the 2moment Thompson et al. (2008) scheme which accounts for graupel, ice, and snow processes. We used the Yonsei University (YSU) planetary boundary layer scheme with nonlocal closure (Hong et al., 2006). Shortwave radiation was parameterized using the Goddard scheme (Chou et al., 2001), while the Rapid Radiative Transfer Model (Mlawer et al., 1997) was used for longwave radiation. At the surface, the NOAH land surface model (Ek et al., 2003) was used with United States Geological Survey (USGS) land use data (including inland lakes) having 30-arcsecond resolution (for d03). The coarser NCEP GFS data did not resolve the lakes of the Tibetan Plateau. Therefore, WRF lake surface temperatures were obtained using an averaging technique described in the WRF User's Manual (ARW WRF User's Guide, 2013). Briefly stated, lake temperatures were computed as the average of neighboring land grid points over the simulation period. Although this is not a perfect representation of the lake temperatures, the technique does eliminate anomalous hot or cold spots due to the unresolved lakes.

\subsection{Simulation period}

The WRF model was used to simulate atmospheric conditions over southeast Asia (Fig. 2) during the 10-day period between 00:00 UTC 10 August and 00:00 UTC 20 August
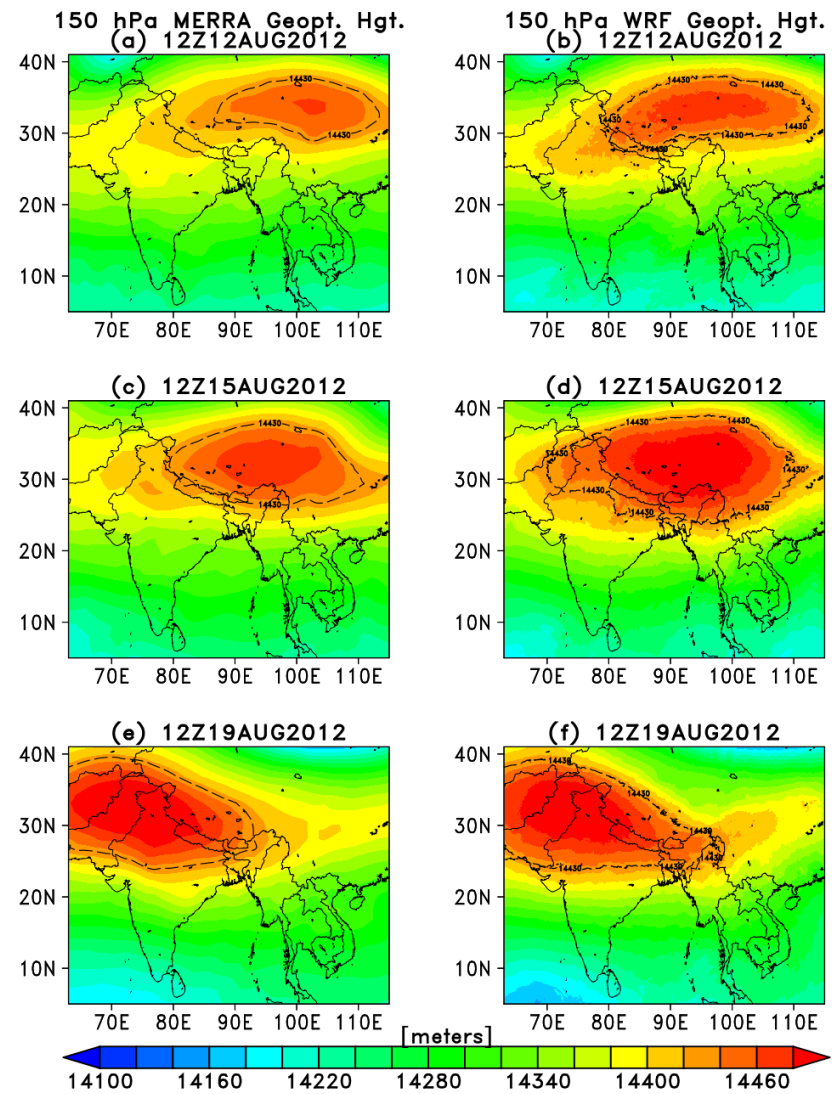

Fig. 3. MERRA (left column) and WRF (right column) geopotential height $(\mathrm{m})$ at $150 \mathrm{hPa}$ for 12:00 UTC 12 August 2012 (a and b), 12:00 UTC 15 August (c and d), and 12:00 UTC 19 August (e and f). The dashed contour represents our definition of the ULAC at this pressure level (14430 m).

2012. The India Meteorological Department's rainfall metric for monsoon intensity indicated that this 10-day period represented "average" conditions (see their image at http://www. imd.gov.in/section/nhac/dynamic/JS_2012.gif). Because the literature has not reached a consensus on the relative importance of different geographic regions within southeast Asia, it was important that convection be well distributed throughout the study domain each day, which this period provided. At the beginning of the period, surface low pressure provided instability and lift for convection over India. This low-pressure system also produced enhanced south/southwest flow over the Bay of Bengal, providing moisture and lift for convection. Over the Tibetan Plateau and southern slope of the Himalayas, diurnal heating provided instability for convection on a daily basis. Additional information about the convection occurring during the simulation is presented in Sect. 3 .

This particular 10-day simulation period also was chosen because the ULAC changed location, size, and shape (Fig. 3). Although this is not unusual, previous climatological studies of the region did not account for these changes. And, because we are specifically examining transport into the ULAC, this 
variability ensured that our results would not be biased toward a particular geographical region; e.g., if the ULAC were stagnant, then one region might appear to dominate another.

\subsection{HYSPLIT model description}

Forward and backward trajectories were computed using the HYSPLIT model (Draxler and Hess, 2010). HYSPLIT interpolates WRF data onto its own terrain-following sigma coordinate system without compromising the vertical resolution of the native WRF output. Advection occurs in a Lagrangian framework, i.e., following the parcel. The time step for integrating the parcel's position varies based on the maximum wind velocity at each grid point (see Draxler and Hess, 1998 for full details). This trajectory framework has been used extensively (e.g., Draxler, 1996), and provides a way to follow individual parcels experiencing deep convection and thereby gain a better understanding of the transport occurring during the ASM.

\subsection{WWLLN data}

Lightning data have proven to be a reliable indicator of deep convection (e.g., Ávila, 2010). Although precipitation data also can be used for locating deep convection, they also capture shallow, warm-rain events that are not the focus of the current study. Thus, in regions of complex terrain and sparse observations, such as the ASM, lightning data can serve as a high-resolution proxy for convection (e.g., Deierling and Petersen, 2008). We used lightning observations from the World Wide Lightning Location Network (WWLLN; http://wwlln.net) during August and September 2007-2012. WWLLN uses a time of group arrival (TOGA; Dowden et al., 2002) technique to locate lightning around the world. Because the location accuracy of WWLLN data in our region is $\sim 15-30 \mathrm{~km}$ (Fig. 5 of Rodger et al., 2009), we binned the WWLLN data into $25 \mathrm{~km}$ grid boxes. The data then were grouped into hourly observations by summing all strokes that occurred \pm 29 min of each hour. For example, if a lightning strike occurred at 00:07:23 UTC (HH:MM:SS), that strike would be recorded as a 00:00:00 UTC strike and placed in the appropriate $25 \mathrm{~km}$ spatial grid box. Using this method, we produced hourly observations of lightning strike "densities" per $25 \mathrm{~km}$ grid box for the abovementioned $6 \mathrm{yr}$ period.

\section{Results and discussion}

\subsection{WRF evaluation}

We first evaluate the performance of the 10-day WRF simulation by comparing it to NASA's Modern-Era Retrospective Analysis for Research and Applications data set (MERRA; Rienecker et al., 2011). With a horizontal grid spacing of $0.5^{\circ}$ latitude $\times 0.67^{\circ}$ longitude, the MERRA reanalysis is an independent data set that can be used to check the performance of
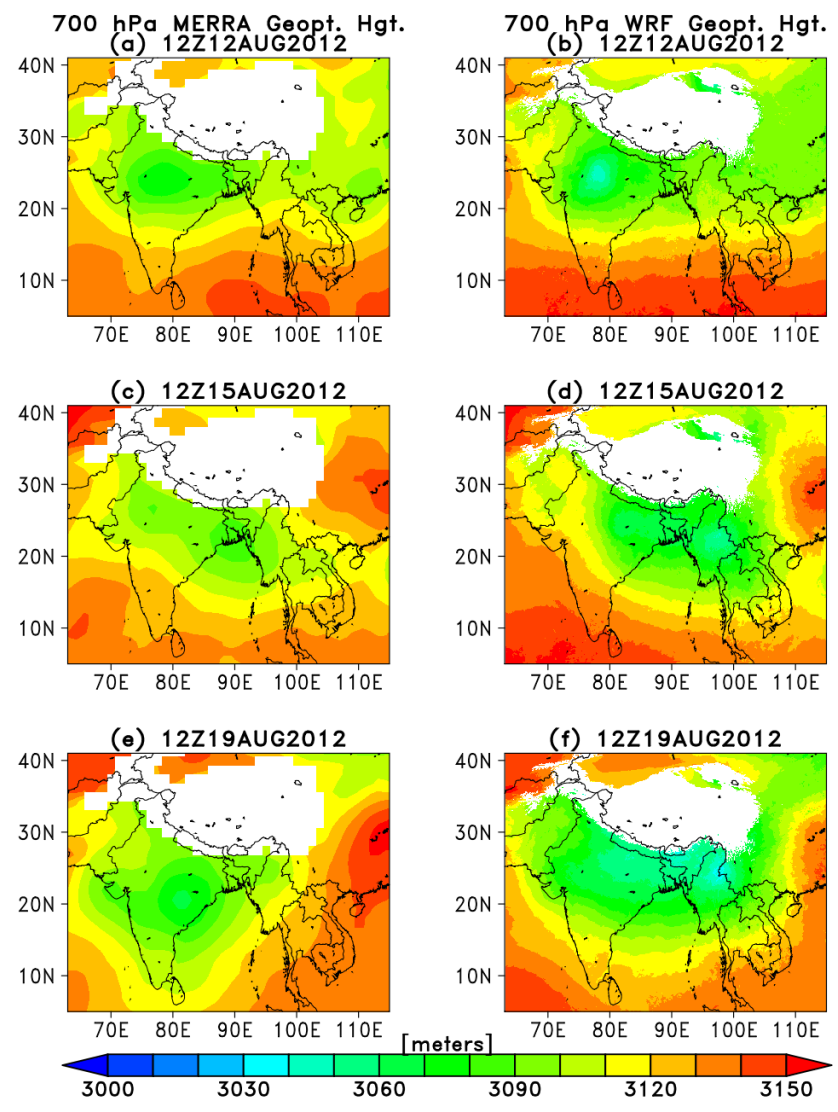

Fig. 4. MERRA (left column) and WRF (right column) geopotential height $(\mathrm{m})$ at $700 \mathrm{hPa}$ for 12:00 UTC 12 August (a and b), 12:00 UTC 15 August (c and d), and 12:00 UTC 19 August (e and f).

WRF on the synoptic scale. Results reveal that the WRF simulation closely captures the general features of the MERRA geopotential heights at $150 \mathrm{hPa}$ (Fig. 3), an important level when considering transport in the ASM UTLS (Dunkerton, 1995). The dashed contour represents our definition of the ULAC at this level $(14430 \mathrm{~m})$. At the beginning of the 10day period, the upper-level anticyclone was centered over the eastern portion of the domain but gradually shifted westward. Figure 3 shows that the WRF simulation captured this shift, along with the observed (according to MERRA) change in shape. Magnitudes of the WRF and MERRA geopotential heights at $150 \mathrm{hPa}$ are similar throughout the simulation (a time-averaged root mean square error of $\sim 22 \mathrm{~m}$ during the simulation period).

The WRF simulation also closely captures synoptic-scale features of the lower to mid-troposphere (700 hPa; Fig. 4) that are indicated by the MERRA reanalyses. The broad region of relatively low geopotential heights, a common feature of the Asian summer monsoon, is represented well in the WRF simulation. WRF again predicts similar geopotential heights compared to the MERRA reanalysis (a time-averaged root mean square error of $\sim 15 \mathrm{~m}$ over the simulation period). 

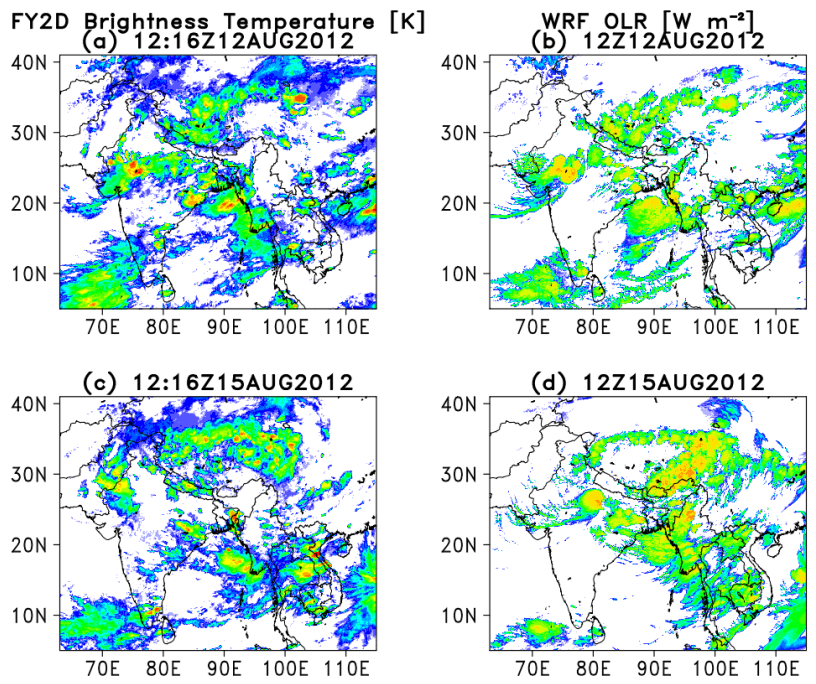

(e) 12:31Z18AUG2012
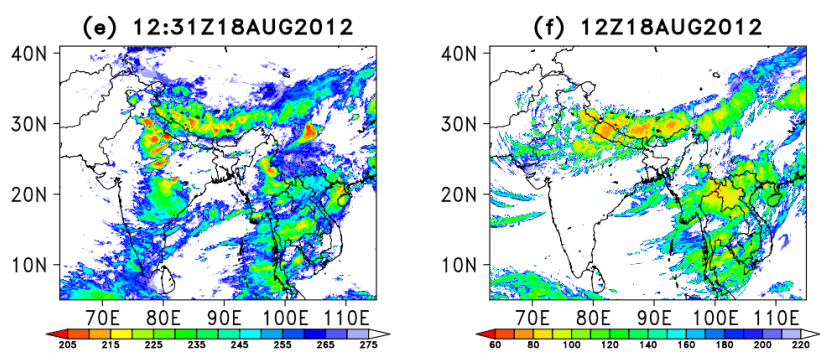

Fig. 5. FY-2D infrared satellite-derived brightness temperature (K; left column) and WRF-simulated outgoing longwave radiation $\left(\mathrm{W} \mathrm{m}^{-2}\right.$; right column) for 12:00 UTC 12 August (a and b), 12:00 UTC 15 August (c and d), and 12:00 UTC 18 August (e and $\mathbf{f})$.

One minor difference is evident at 9.5 days into the simulation (Fig. 4f) when WRF produces a weak, secondary region of low pressure in the eastern portion of the domain $\left(\sim 98^{\circ} \mathrm{E}\right.$, $26^{\circ} \mathrm{N}$ ) that is not apparent in the MERRA reanalysis. Additionally, MERRA shows the low pressure extending farther south over India when compared to WRF (Fig. 4e versus 4f).

We next compare WRF-simulated outgoing longwave radiation (OLR; a proxy for convection) to Fengyun (FY)-2D gridded infrared satellite-derived brightness temperatures to confirm that WRF is simulating convection in the correct locations. The gridded FY-2D data were provided by the Center for Environmental Remote Sensing, Chiba University, on a $4 \mathrm{~km} \times 4 \mathrm{~km}$ grid (available at ftp://fy.cr.chiba-u. ac.jp/grided/). Figure 5 shows both parameters at 12:00 UTC on 12, 15, and 18 August 2012. Because we are comparing "apples to oranges" (OLR to brightness temperature), Fig. 5 shows only that WRF captures the general features of the convection; however, we cannot quantify whether the intensities of WRF convection match those observed. Note that, even at 8.5 days into the run (Fig. 5e, f), WRF correctly places convection in many regions that agree with observations. For example, WRF closely simulates the line of convection stretching from northwest India over the Tibetan Plateau. However, Fig. 5e and $\mathrm{f}$ also reveal that WRF missed the convection occurring over central India.

Because WRF closely simulates general synoptic features of the upper and lower troposphere, and places convection in locations that generally agree with satellite observations (albeit with some differences), we are confident that WRF is simulating the real atmosphere sufficiently well to investigate convective transport into the ULAC at a resolution that previously has not been documented.

\subsection{Back-trajectory analysis}

Convective transport into the ULAC is examined with back trajectories from HYSPLIT using the hourly WRF data. The ULAC was defined as the $14430 \mathrm{~m}$ geopotential height contour at $150 \mathrm{hPa}$, and the $16830 \mathrm{~m}$ contour at $100 \mathrm{hPa}$. These values were chosen because their contours almost always remained closed within our domain throughout the entire simulation. Other values were tested to ensure that our results were not compromised by the choice of these specific values. The GFS FNL data indicated that the lapse-rate-derived tropopause (WMO definition) was located between 105 and $95 \mathrm{hPa}$ during the simulation. Therefore, the two chosen pressure surfaces correspond to just below $(150 \mathrm{hPa})$ and very near $(100 \mathrm{hPa})$ the tropopause level. Dunkerton (1995) proposed that these two pressure altitudes are best suited for understanding the response of the UTLS to tropical convection in the ASM region. At each hour of the WRF simulation, we recorded the latitude, longitude, and geopotential height of each grid point within the defined ULAC. Six-hour back trajectories then were released hourly from these locations between 00:00 UTC 11 August and 23:00 UTC 19 August. This method accounted for the movement and change in shape and/or area of the ULAC seen in Fig. 3. For example, at one hour, we might have released 100000 back trajectories, but at another, if the ULAC had expanded, we might have released 350000 back trajectories.

We defined convective trajectories as those reaching the planetary boundary layer (PBL) at some time during their $6 \mathrm{~h}$ back track. Further analysis of the updraft strengths associated with these $6 \mathrm{~h}$ trajectories is discussed in Sect. 3.3. Note that the $6 \mathrm{~h}$ cutoff is consistent with our goal of analyzing rapid vertical transport into the ULAC. However, parcels that are lofted to the upper levels in regions that do not directly impact the ULAC and are subsequently transported horizontally into the ULAC at timescales longer than $6 \mathrm{~h}$ will not be represented. We denoted the location where each convective trajectory crossed the top of the PBL (PBLH) as its origin. By finding locations where the trajectories crossed the PBLH, we sought to locate convectively influenced air with boundary layer characteristics (typically enhanced $\mathrm{CO}$ concentration and diminished $\mathrm{O}_{3}$ concentration), which are often observed in the ASM ULAC (see Park et al. (2007) 

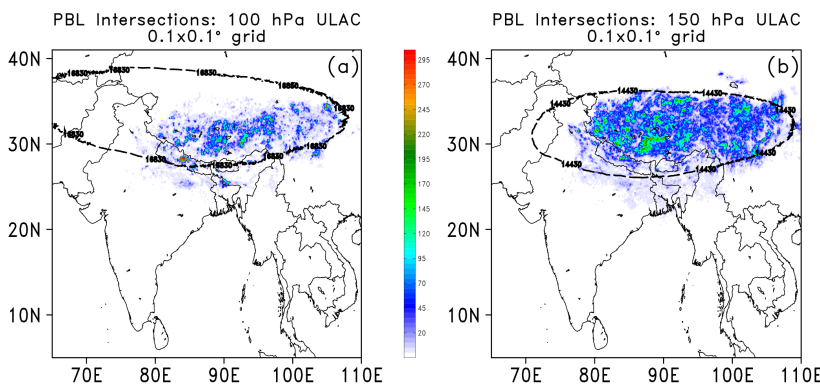

Fig. 6. Locations where convective back trajectories originating at $100 \mathrm{hPa}$ (a) and $150 \mathrm{hPa}$ (b) cross the PBLH, binned into $0.1^{\circ} \times 0.1^{\circ}$ cells. The dashed contour at each pressure altitude represents the time-averaged location of the ULAC during the simulation. The color bar indicates the number of trajectories that cross the PBLH in each $0.1^{\circ} \times 0.1^{\circ}$ cell.

for a discussion of how to differentiate tropospheric air from stratospheric air based on $\mathrm{CO}$ and $\mathrm{O}_{3}$ concentrations).

With the ULAC defined as $150 \mathrm{hPa}$, a total of 51830940 back trajectories were released, of which 983518 (1.9\%) were classified as convective. At $100 \mathrm{hPa}, 62277179$ back trajectories were released from the ULAC, of which 318277 $(0.5 \%)$ were considered convective. These percentages of convective parcels agree with previous satellite studies of tropical convection. For example, Liu and Zipser (2005) showed that $\sim 1.3 \%$ of tropical convection reaches $14 \mathrm{~km}$, similar to our $150 \mathrm{hPa}$ results. Further, Gettelman et al. (2002) found that $\sim 0.5 \%$ of tropical convection reaches the cold point tropopause, similar to our $100 \mathrm{hPa}$ results. This indicates that our $6 \mathrm{~h}$ cutoff is doing a reasonable job of isolating only deep convection, which is the goal of this study. Also, the $1.4 \%$ decrease in the number of convective trajectories reaching the $100 \mathrm{hPa}$ ULAC versus the $150 \mathrm{hPa}$ ULAC is an indicator of the variability that exists between those two pressure levels. Note, however, that this does not indicate that $\sim 99 \%$ of ULAC parcels were not influenced by convection at some point. Longer back trajectories likely would lead to greater convective percentages, but would also include slower-scale processes that are not the focus of the current study. For example, Bergman et al. (2013), using global models, released 30-day back trajectories from the ULAC. Their results indicated that $78 \%$ of ULAC parcels reached the PBL during their 30-day back track. They note that small-scale deep convection, which is not well resolved by the global models, likely is important for transport into the $100 \mathrm{hPa}$ ULAC. Thus, our results complement their study by examining the role of this unresolved (by global models) transport. Figure $6 \mathrm{a}$ and $\mathrm{b}$ show the PBLH origins of the convective back trajectories, binned into $0.1^{\circ} \times 0.1^{\circ}$ cells, along with the average location of the ULAC at 100 and $150 \mathrm{hPa}$. The colored areas represent the number of trajectories that crossed the PBLH in each $0.1^{\circ} \times 0.1^{\circ}$ cell. Thus, they represent a density of convective trajectory origins. One should note that most of the convective trajectories reaching the 100 and $150 \mathrm{hPa}$ ULAC originated from the Tibetan Plateau and southern slope of the Himalayas. Also note that there likely would be a greater spread among the PBL intersections (Fig. 6) if the back trajectories were released for a longer duration (e.g., see Fig. 4 of Bergman et al., 2013).

To quantify the geographic origins of the convective trajectories, we defined regions of interest as in previous studies of ASM convection (e.g., Fu et al., 2006; Park et al., 2009; Luo et al., 2010; Wright et al., 2011; Chen et al., 2012). Specifically, we defined the Tibetan Plateau (TP) as the area with an elevation $>3 \mathrm{~km}$ within $25-40^{\circ} \mathrm{N}$ and $70-105^{\circ} \mathrm{E}$, the southern slope (SS) as the area with elevation $<3 \mathrm{~km}$ within 25 $35^{\circ} \mathrm{N}$ and $70-105^{\circ} \mathrm{E}$, the Bay of Bengal (BOB) as the area within $15-25^{\circ} \mathrm{N}$ and $85-97^{\circ} \mathrm{E}$, and India (IND) as the area within $10-25^{\circ} \mathrm{N}$ and $70-85^{\circ} \mathrm{E}$. The TP and SS definitions are identical to those of Fu et al. (2006) and Luo et al. (2010). Figure $7 \mathrm{a}$ and $\mathrm{b}$ show the number of convective trajectories that originated, i.e., crossed the PBLH, within each of these regions from 100 and $150 \mathrm{hPa}$, respectively. Thus, the figure shows locations where polluted boundary layer air is most likely to enter the ULAC recently (in the last $6 \mathrm{~h}$ ) via convective transport. Greater than $90 \%$ of the convective (not total) trajectories originated in either the TP or SS regions at both 100 and $150 \mathrm{hPa}$. These results are consistent with the findings of $\mathrm{Li}$ et al. (2005), Fu et al. (2006), and Wright et al. (2011). However, they are inconsistent with Park et al. (2007, 2009), James et al. (2008), and Chen et al. (2012), who argued that convection over the TP is not sufficiently deep or frequent to impact the composition of the UTLS.

Figure $8 \mathrm{a}$ and $\mathrm{b}$ show the times when convective back trajectories from 100 and $150 \mathrm{hPa}$ cross the PBLH. At $150 \mathrm{hPa}$ (Fig. 8b), there is a distinct diurnal cycle, with most convective trajectories reaching the PBLH during the afternoon and late evening. This trend also is seen at $100 \mathrm{hPa}$ (Fig. 8a). The large convective event seen in Fig. 8a on 16 August will be discussed in Sect. 3.3. The diurnal cycle of convective back trajectories is depicted further in histograms (Fig. 9a, b), which indicate the time of day when convective trajectories cross the PBLH regardless of date. After local solar noon ( 06:00 UTC), the number of convective trajectories reaching the PBLH increases rapidly and continues to increase through the early nighttime (Fig. 9). The large diurnal cycle seen in Figs. 8 and 9, with the peak in convective transport occurring between 10:00 and 17:00 UTC (16:00 and 23:00 LST), is consistent with previous observational studies of convection over the TP and SS regions (e.g., Liping et al., 2002; Barros et al., 2004; Hirose et al., 2005; Yaodong et al., 2008; Luo et al., 2010; Romatschke et al., 2010). Our WRF simulation and HYSPLIT back trajectories emphasize the importance of diurnal convection in transporting boundary layer air to the ULAC.

The ULAC back-trajectory analysis highlighted the importance of convection over the Tibetan Plateau in affecting the composition of the ULAC (Fig. 7). To confirm the validity of 
$100 \mathrm{hPa}$ ULAC
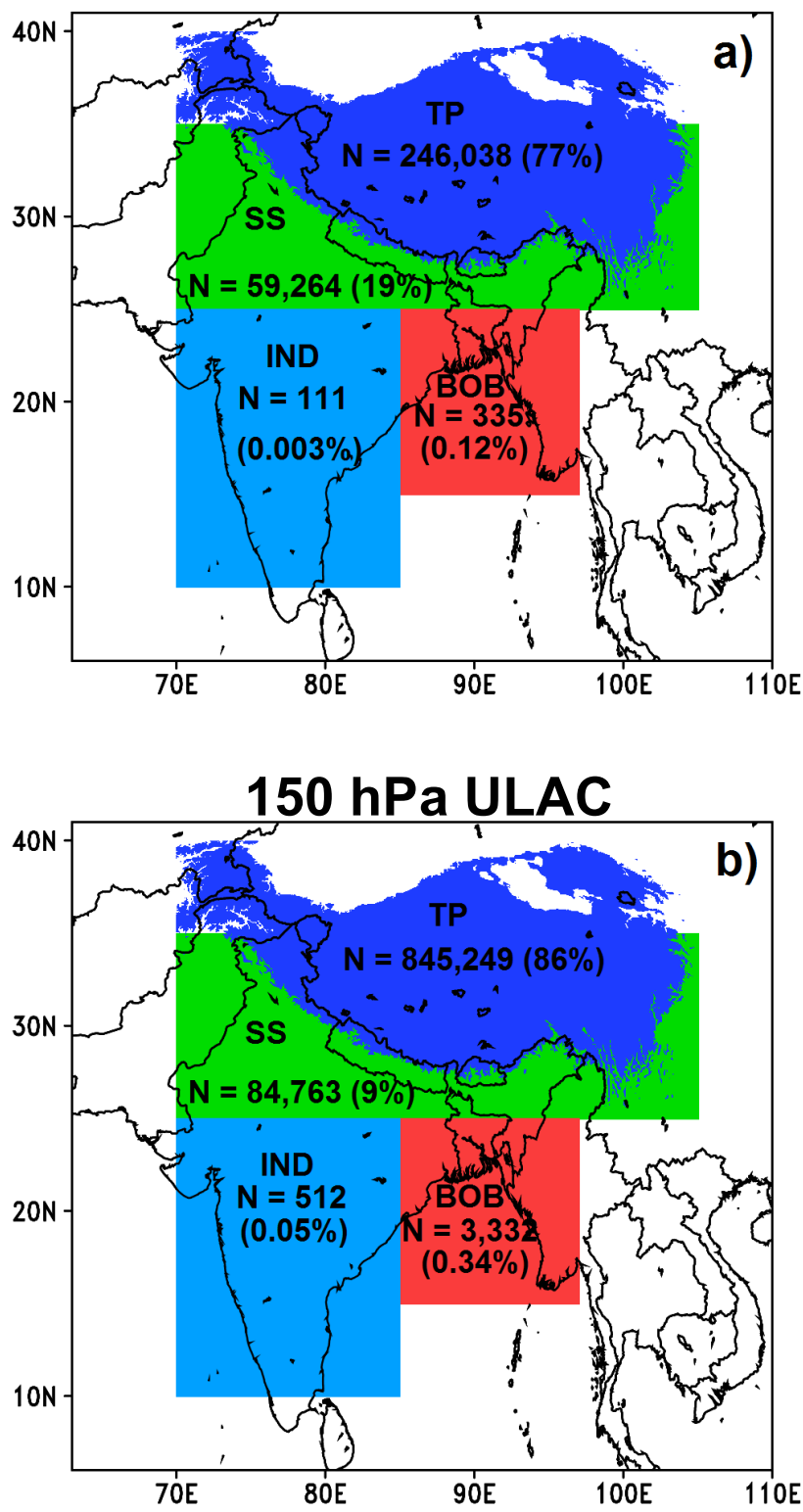

Fig. 7. The number and percentage of back trajectories starting at the ULAC at $100 \mathrm{hPa}$ (a) and $150 \mathrm{hPa}$ (b) that crossed the PBLH in each region of interest (the convectively influenced trajectories).

this simulated convection, WWLLN-observed total lightning within the TP region (blue line in Fig. 10) is overlaid with the number of convective back trajectories from the ULAC at $150 \mathrm{hPa}$ (black line). The timing of the observed lightning over the TP closely matches the timing of the simulated convective back trajectories, but with a slight shift. Petch et al. (2002) showed that, to accurately represent the timing of convective initiation over land, simulations must be made at a grid spacing of less than $1 \mathrm{~km}$. The $4 \mathrm{~km}$ grid spacing of the current WRF simulation might be delaying the onset of convection over the TP, thus accounting for the slight phase shift observed in Fig. 10. However, because the Tibetan Plateau was the origin of $86 \%$ of the convective back trajectories released from the ULAC at $150 \mathrm{hPa}$, Fig. 10 indicates that WRF is realistically simulating the diurnal nature of the convective transport, and again highlights the importance of convection in this region.

\subsection{Details of convective transport: 16 August 2012}

This section further explores the details (e.g., updraft strength) of convective transport occurring in each of our defined regions (Fig. 7), without requiring that the convective trajectories actually enter the ULAC. WRF output at greater temporal resolution than hourly was needed for this purpose. Therefore, we produced output at $15 \mathrm{~min}$ intervals between 00:00 UTC 16 August and 05:00 UTC 17 August. This period includes the large spike of convective back trajectories from $100 \mathrm{hPa}$ that reach the PBL on 16 August (Fig. 8a). This spike in the number of convective trajectories reaching $100 \mathrm{hPa}$ might have been influenced by the increasing tropopause height indicated by the GFS FNL data set (changing from $\sim 106$ to $\sim 100 \mathrm{hPa}$ ). Nonetheless, simulated convection was present in all four of our defined regions (TP, SS, BOB, and IND; not shown). We then performed a forwardtrajectory study using the 15 min output. Six-hour forward trajectories were released at $10 \mathrm{~m}$ above ground level (AGL) at every grid point within the defined regions each hour on 16 August. Convective trajectories were defined as those that reached the $150 \mathrm{hPa}$ surface during their $6 \mathrm{~h}$ forward transit. Similar results were found using a $100 \mathrm{hPa}$ threshold (not shown). If a trajectory reached the $150 \mathrm{hPa}$ surface within $6 \mathrm{~h}$, we marked the location where it crossed this surface, and recorded the time required to travel from the PBL to $150 \mathrm{hPa}$. Note again that we did not require the trajectory to enter the ULAC, but only that it reach $150 \mathrm{hPa}$.

Table 1 shows the number of forward trajectories released from each region, the number that reached the $150 \mathrm{hPa}$ surface, and the average and maximum column-averaged vertical velocities $(\mathrm{W})$. The column-averaged vertical velocity of each trajectory was determined by dividing the vertical distance between the PBLH and $150 \mathrm{hPa}$ by the time (to within $15 \mathrm{~min}$ ) required to reach that altitude. The SS region exhibits the strongest vertical motions (maximum $\mathrm{W}$ of $\sim 23 \mathrm{~m} \mathrm{~s}^{-1}$ ), although not the most frequent, followed by the BOB (maximum $\mathrm{W}$ of $\sim 21 \mathrm{~m} \mathrm{~s}^{-1}$ ), and finally the IND and TP regions (maximum $\mathrm{W}$ of $\sim 20 \mathrm{~m} \mathrm{~s}^{-1}$ and $\sim 17 \mathrm{~m} \mathrm{~s}^{-1}$, respectively). These relative strengths (e.g., the SS having a stronger $\mathrm{W}$ than the $\mathrm{TP}$ ) are consistent with the observational findings of Houze et al. (2007), Luo et al. (2010), and Romatschke et al. (2010). Furthermore, the column-averaged updraft strengths in each region (Table 1) are consistent with those of deep convection occurring in nature (Markowski and Richardson, 2010), indicating that the convective-permitting WRF is simulating the deep convection realistically. Although these vertical velocities are realistic for an isolated 

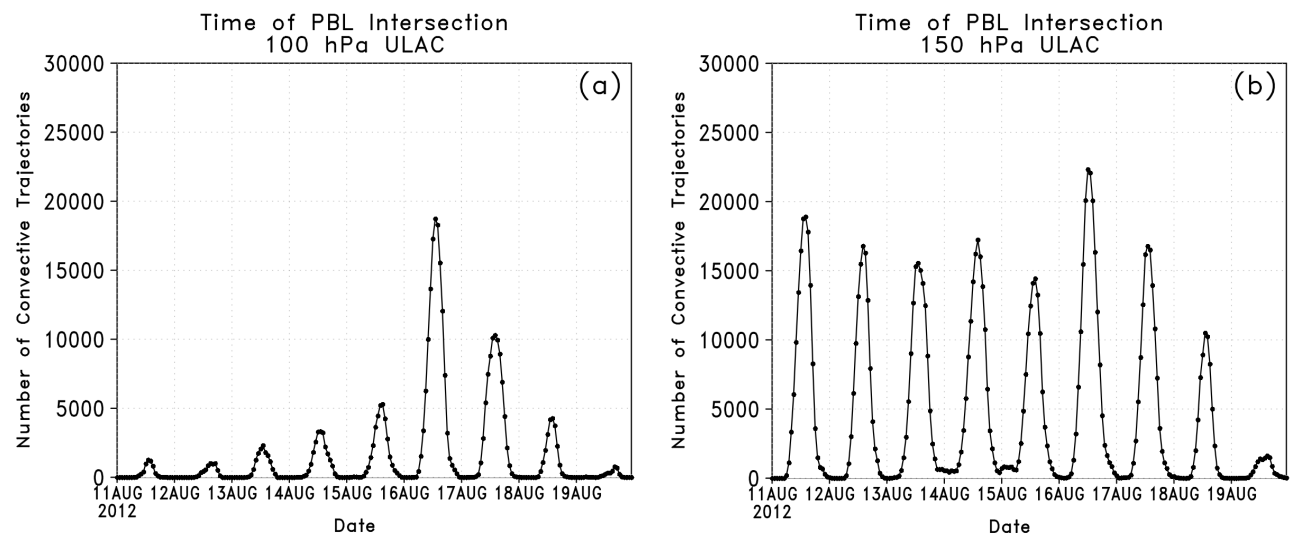

Fig. 8. The number of convective trajectories starting at $100 \mathrm{hPa}$ (a) and $150 \mathrm{hPa}$ (b), and the time (UTC) at which they crossed the PBLH during the runtime.

Table 1. Results from the 15 min forward-trajectory analysis for each region in Fig. 7.

\begin{tabular}{lllll}
\hline Region & Total trajectories & Convective trajectories & Average W & Maximum W \\
\hline TP & 5046336 & $239251(4.7 \%)$ & $8 \mathrm{~m} \mathrm{~s}^{-1}$ & $17 \mathrm{~m} \mathrm{~s}^{-1}$ \\
SS & 3127224 & $51382(1.6 \%)$ & $9 \mathrm{~m} \mathrm{~s}^{-1}$ & $23 \mathrm{~m} \mathrm{~s}^{-1}$ \\
BOB & 2004096 & $25448(1.3 \%)$ & $9 \mathrm{~m} \mathrm{~s}^{-1}$ & $21 \mathrm{~m} \mathrm{~s}^{-1}$ \\
IND & 3695184 & $4449(0.1 \%)$ & $10 \mathrm{~m} \mathrm{~s}^{-1}$ & $20 \mathrm{~m} \mathrm{~s}^{-1}$ \\
\hline
\end{tabular}

updraft, note that they represent a $16 \mathrm{~km}^{2}$ horizontal average because of the grid spacing of the WRF simulation. Updrafts of this strength are not expected to exist over such large horizontal areas in nature. Also, the average could be dominated by the value at a particular level; e.g., the updraft could have been $\sim 30 \mathrm{~m} \mathrm{~s}^{-1}$ at $500 \mathrm{hPa}$, but much smaller at other levels.

It is important to note that, although convective vertical motions over the TP region are weaker than in the other three regions, its trajectories still reach the $150 \mathrm{hPa}$ surface more frequently than those from the other regions (Table 1). Because the height of the Tibetan Plateau is 3000 $5000 \mathrm{~m}$ a.m.s.l., the highest of the four regions, its convection does not have to be as deep to reach the $150 \mathrm{hPa}$ surface. Note that, due to the warmer column of air above the TP, the $150 \mathrm{hPa}$ surface also is higher over this region ( $\sim 95 \mathrm{~m}$ higher than over the BOB). However, this slightly higher altitude of the $150 \mathrm{hPa}$ surface is small compared to the greater terrain height of the TP. We conclude that the higher surface elevation of the TP allows diurnally driven convection (Figs. 8 and 9) with comparatively weaker updrafts (Table 1) to impact the UTLS more frequently, whereas convection in other regions must be deeper to penetrate the UTLS.

Based on the abovementioned results, we hypothesize that convection in the TP region is most favorable for impacting the ULAC because of its elevation and geographic location. The ASM upper-level anticyclone is a result of the elevated heat source of the Tibetan Plateau and latent heat release from ASM convection (e.g., Hoskins and Rodwell,
1995; Duan and Wu, 2005; Wu et al., 2012). Although the ULAC does oscillate somewhat in location and strength (Krishnamurti et al., 1973; our Fig. 3), it is always thermally linked to the TP due to its elevation. Thus, convection occurring over the TP, and neighboring SS, is favored for affecting the composition of the ULAC. Deep convection certainly occurs in locations other than the TP and SS (Table 1); however, the geographic locations of the TP and SS make them especially prone to impact the ULAC.

\subsection{Vertical flux of water vapor}

An important aspect of ASM deep convection is its role in transporting water vapor into the ULAC and thus its role in affecting the $\mathrm{H}_{2} \mathrm{O}$ maximum observed in Fig. 1. Water vapor is a greenhouse gas that can influence the radiation budget at upper levels, thus causing a positive feedback on climate (Held and Soden, 2000; Gettelman and Fu, 2007). Moreover, if water vapor enters the lower stratosphere, it can deplete ozone in what is referred to as a catalytic loss cycle (Jacob, 1999; Stenke and Grewe, 2005). Gettelman et al. (2004) showed that the ULAC could account for $75 \%$ of the total upward water vapor flux at tropopause levels in the tropics. Thus, it is important that regional and global climate studies faithfully simulate the processes controlling ULAC water vapor content. 


\section{Convective Trajectories from $100 \mathrm{hPa}$ ULAC}

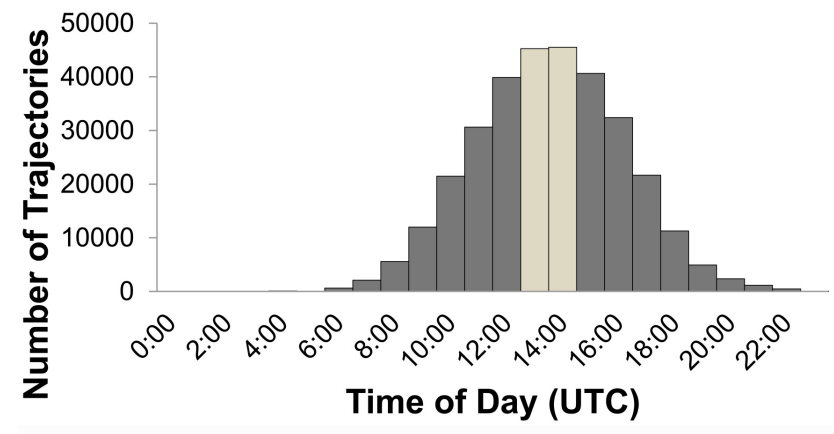

\section{Convective Trajectories from $150 \mathrm{hPa}$ ULAC}

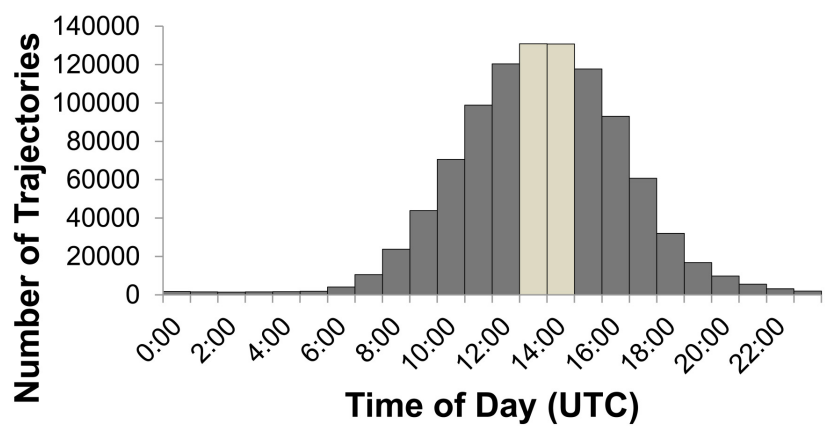

Fig. 9. Histograms of the time of day (UTC) that convective back trajectories starting from the ULAC at $100 \mathrm{hPa}$ (a) and $150 \mathrm{hPa}$ (b) crossed the PBLH.

To analyze transport into the ULAC, we calculated vertical fluxes of water vapor passing through the 100 and $150 \mathrm{hPa}$ surfaces similar to the method of Halland et al. (2009):

$M_{\mathrm{v}}=\frac{\Sigma_{\mathrm{ULAC}} \frac{M C \times w \times A \times t}{1000}}{\text { ULAC Area }}$,

where $M_{\mathrm{v}}$ is the vertical water vapor mass flux in metric tons per square kilometer per time step, $M C$ is the mass concentration of water vapor $\left(\mathrm{kg} \mathrm{m}^{-3}\right)$, w is the vertical velocity $\left(\mathrm{m} \mathrm{s}^{-1}\right), \mathrm{A}$ is the area of the model grid box $\left(16000 \mathrm{~m}^{2}\right)$, and $\mathrm{t}$ is the time step $(3600 \mathrm{~s})$. We summed the fluxes over all ULAC grid points and normalized them by the area $\left(\mathrm{km}^{2}\right)$ of the ULAC to account for its changing size at every time step. The ideal gas law was used to calculate MC from our WRF output:

$M C=\frac{P_{\mathrm{L}} \times M \times C}{R \times T}$,

where $P_{\mathrm{L}}$ is the pressure level at which the computation is made $(\mathrm{Pa}), M$ is the molecular weight of water vapor $\left(18.01528 \mathrm{~g} \mathrm{~mol}^{-1}\right), C$ is the model-calculated water vapor mixing ratio (ppbv), $R$ is the universal gas constant

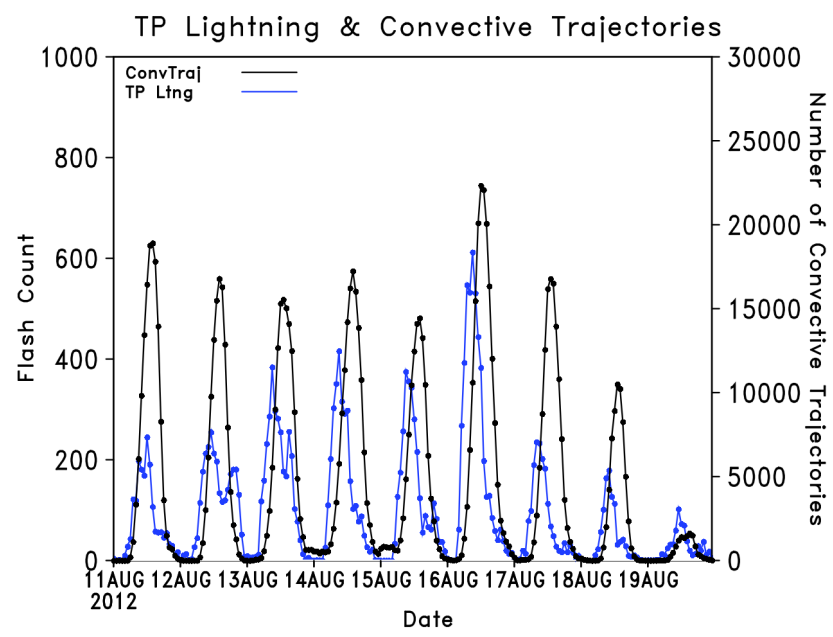

Fig. 10. As in Fig. 8 b (black line, $150 \mathrm{hPa}$ ) overlaid with the WWLLN total lightning flash count over the Tibetan Plateau (blue line) at each hourly time step (UTC).

( $8.3144 \mathrm{~J} \mathrm{~mol}^{-1} \mathrm{~K}^{-1}$ ), and $T$ is the model-calculated temperature $(\mathrm{K})$. Note that this method accounts only for the vertical transport of water vapor into the ULAC and does not consider the role of horizontal advection into the ULAC. This again is consistent with our specific goal of examining rapid vertical transport into the ULAC.

Figure 11 shows a time series of total vertical water vapor mass flux into the ULAC independent of region (black), along with the regional component amounts. Diurnal convection in the TP region is the dominant source at $150 \mathrm{hPa}$ (Fig. 11b), followed by the southern slope. At $100 \mathrm{hPa}$ (Fig. 11a), the convective diurnal cycle still is prominent; however, the TP and SS regions make similar contributions to the ULAC water vapor content. Referring back to Table 1, these results agree with the convective characteristics of the SS region; i.e., strong convective updrafts in the SS region are favorable for transporting large amounts of moisture to $100 \mathrm{hPa}$. Fu et al. (2006) also found that convection over the Tibetan Plateau and southern slope was dominant in controlling the water vapor content at upper levels. The current results (Fig. 11) also are consistent with a global water vapor flux analysis by Lelieveld et al. (2007), who proposed that the Tibetan Plateau is a favorable region for stratospheric moistening. Conversely, the BOB and IND regions transport a negligible amount of water vapor mass flux to the ULAC at 100 and $150 \mathrm{hPa}$. This too is consistent with the back-trajectory analysis (e.g., Fig. 7), which showed that less than $1 \%$ of the convective trajectories entering the ULAC originated from these regions. The flux calculations (Fig. 11) again highlight the role of diurnal convection in transporting water vapor into the ULAC. However, note that the dominant role of the $\mathrm{TP}$ and SS regions in moistening the ULAC does not imply that they transport more pollutants into the upper levels 

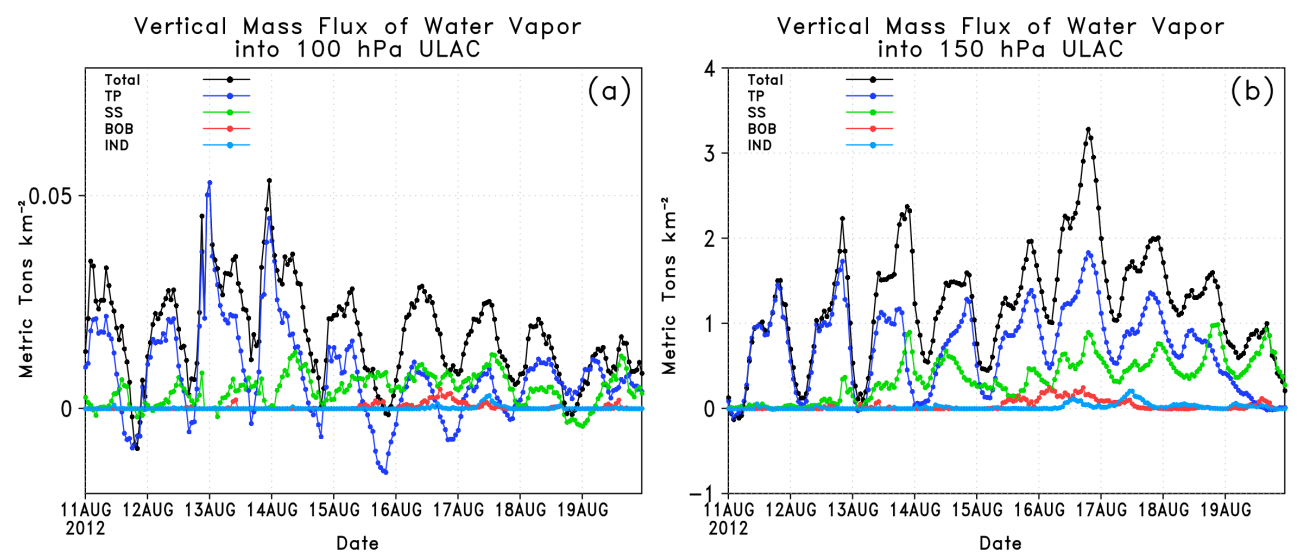

Fig. 11. Vertical water vapor mass flux (metric tons $\mathrm{km}^{-2}$ ) into the ULAC at $100 \mathrm{hPa}$ (a) and $150 \mathrm{hPa}$ (b). The black line indicates the total mass flux, and the colors indicate the amount from each defined region (Fig. 7). Note the two-orders-of-magnitude change between 150 and $100 \mathrm{hPa}$.
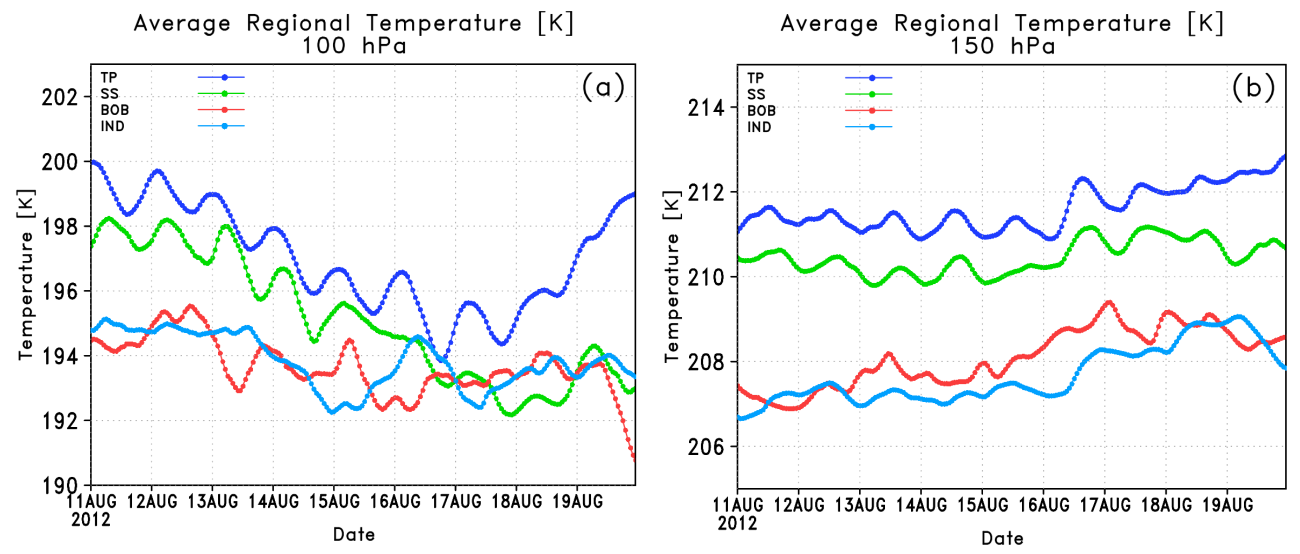

Fig. 12. WRF-simulated area average temperature (K) at $100 \mathrm{hPa}(\mathbf{a})$ and $150 \mathrm{hPa}(\mathbf{b})$ for the $\mathrm{TP}, \mathrm{SS}, \mathrm{BOB}$, and IND regions.

because pollution transport depends on their source distributions, which were not considered in the current study.

Similar to Fu et al. (2006), we argue that the thermodynamic environments of the TP and SS make them favorable for convection to moisten the upper levels. Compared to the other regions, the elevated surface of the Tibetan Plateau produces warmer temperatures in the UTLS. Figure 12 shows the WRF-simulated area average temperature in each region at $100 \mathrm{hPa}$ (Fig. 12a) and $150 \mathrm{hPa}$ (Fig. 12b). The TP and SS regions are several degrees warmer than the BOB and IND regions at both pressure altitudes. Because of this warmer upper-level ambient environment, parcels entering the ULAC will have a greater saturation mixing ratio $(\sim 2 \times$ that of the $\mathrm{BOB}$ and IND regions at $150 \mathrm{hPa}$ ), potentially allowing them to make a greater contribution to the ULAC's water vapor content. Results of the water vapor flux calculations (Fig. 11) highlight the importance of this warmer upper-level ambient environment over the Tibetan Plateau. Specifically, magnitudes of vertical moisture flux depend on both vertical velocity and water vapor mixing ratio (Eq. 1). Because we already showed that vertical velocities over the Tibetan Plateau are weaker (Table 1) than in other regions, the greater flux values over the TP appear to be the result of greater water vapor content at the upper levels. Furthermore, because convection affecting the ULAC is more widespread in the TP than the other regions (e.g., Fig. 6), this also contributes to the greater TP flux observed in Fig. 11.

The warmer temperatures over the Tibetan Plateau (Fig. 12) also might enhance the cirrus-lofting mechanism proposed by Corti et al. (2006). That is, more outgoing longwave radiation reaches the upper levels over the Tibetan Plateau because of its high altitude, allowing remnant cirrus clouds to warm (due to the increased OLR) and produce regions of ascent. Thus, TST within the ULAC might be more efficient over the TP due to this enhanced cirrus lofting. Referring back to Fig. 6b, convection reaching the ULAC at $150 \mathrm{hPa}$ is ubiquitous over the Tibetan Plateau. If pollution were to be advected horizontally into this region (e.g., from northern India or mid-eastern China), TP convection could transport that pollution into the UTLS via direct convective 
injection, gradual ascent within the ULAC, or the proposed enhanced cirrus lofting.

\subsection{Lake-influenced convection over the Tibetan Plateau}

Because the TP has stood out in all of the previous results, in this section we examine the mechanisms that drive its convection. Convection over the Tibetan Plateau mostly is the result of diurnal heating and orographic lift (Liping et al., 2002; Kurosaki and Kimura, 2002; Yaodong et al., 2008; Romatschke et al., 2010). The strong surface heating and subsequent rising motion (e.g., dry thermals) over the TP is associated with low-to-mid-level horizontal convergence, transporting moisture from the surrounding regions ( $\mathrm{Wu}$ et al., 1997; Carrico et al., 2003; Fu et al., 2006). This moisture, the instability generated by diurnal heating, and mesoscale trigger mechanisms such as orographic lift all combine to support the development of diurnal convection in this region. However, we hypothesize that the Tibetan lakes at night also provide a mesoscale source of moisture, instability, and convergence to support deep convection. Lake-effect convection occurs when cooler air is advected over a relatively warmer body of water. The warm water surface provides heat and moisture fluxes which can destabilize the air and ultimately produce convection (Markowski and Richardson, 2010). Lake-effect convection is common downwind of the North American Great Lakes (e.g., Niziol et al., 1995). However, to our knowledge, lake-influenced convection over the Tibetan Plateau has not previously been documented.

Figure 13a shows a zoomed view of the terrain over the Tibetan Plateau, with black Xs marking the Tibetan lakes. Small-scale hills and valleys are located around the lakes. Small-scale topographic features such as these have been shown to trigger convection in the monsoon region (Barros et al., 2004). At night, as the land cools rapidly but the lake temperatures remain almost constant, relatively cool air is advected over the relatively warm lakes, where it receives added heat and moisture that could enhance convective development. Nighttime downslope flow associated with the small-scale topographic features (Fig. 13a) also could enhance convergence over the lakes. Our lake-effect hypothesis is supported by the WWLLN lightning climatology (Fig. 13b) that shows total lightning between 1500 and 04:00 UTC (late afternoon through nighttime) during August and September 2007-2012. Because the "hot spots" near the lakes appear in the observed WWLLN lightning data, there is observational evidence that lake-influenced convection is occurring on the Tibetan Plateau and that the lakes provide a mesoscale moisture source for the ULAC. Because the detection efficiency of WWLLN improved from 2007 to 2012, we also examined each year individually. This revealed that the signal seen in Fig. 13b was dominated by the most recent three years $(2010,2011,2012)$. The signal still was apparent in the earlier years $(2007,2008,2009)$, just not as strong.
Daytime plots of WWLLN lightning (not shown) do not exhibit the geographic hot spots seen at night.

We propose that convection at night is focused over the lake regions due to the mechanism described above. Although the lakes do not stand out as hot spots in our ULAC back-trajectory analysis (Fig. 6), we believe this is due to the method used to obtain lake surface temperatures in our WRF simulation (see the end of Sect. 2.1). The overall impact of the lakes on Tibetan Plateau convection is a topic that should be explored further; however, we believe that the lightning maxima point to them as a mesoscale mechanism leading to TP convection after daytime heating subsides.

\section{Summary and conclusions}

The Asian summer monsoon (ASM) is a dominant feature of the global circulation. Satellite observations of the upper troposphere/lower stratosphere (UTLS) highlight the importance of the ASM upper-level anticyclone (ULAC) in affecting the chemical composition of these levels (Fig. 1). Previous studies have shown that troposphere-to-stratosphere transport (TST) is enhanced within the ULAC, emphasizing its importance to UTLS chemistry. However, the processes controlling the composition of the ULAC are not fully understood nor agreed upon. Deep convection generally is accepted as an important mechanism for transporting surfacebased emissions into the ULAC. However, previous studies that have examined convective transport into the ULAC have reached varying, often conflicting conclusions as to which geographic region contains the convection that most impacts the ULAC. These differing conclusions partially are a result of using coarse-resolution numerical models and observations that are limited in both time and space.

We have used a convective-permitting (4 km grid spacing) WRF simulation to examine rapid convective transport into the ULAC. To our knowledge, such high-resolution modeling has not been used previously to study convective transport in the ASM region. We ran WRF from 00:00 UTC 10 August to 00:00 UTC 20 August 2012. Comparisons with independent reanalyses and satellite observations revealed that the WRF simulation closely captured the synoptic-scale features of the upper and lower troposphere, and generally placed convection in regions that agreed with observations. Therefore, the simulation was suitable for more detailed analyses.

We defined the ULAC as the $14430 \mathrm{~m}$ geopotential height contour at $150 \mathrm{hPa}$ and the $16830 \mathrm{~m}$ contour at $100 \mathrm{hPa}$. Then, using our WRF output and HYSPLIT, we released $6 \mathrm{~h}$ back trajectories from every grid point within the ULAC at $1 \mathrm{~h}$ intervals. This method allowed us to account for the observed changes in position and shape of the ULAC during the simulation period (Fig. 3). We defined convective trajectories as those that started at the ULAC and reached the top of the boundary layer at some time during their $6 \mathrm{~h}$ back track. At 150 and $100 \mathrm{hPa}, 1.9$ and $0.5 \%$ of the ULAC parcels, 

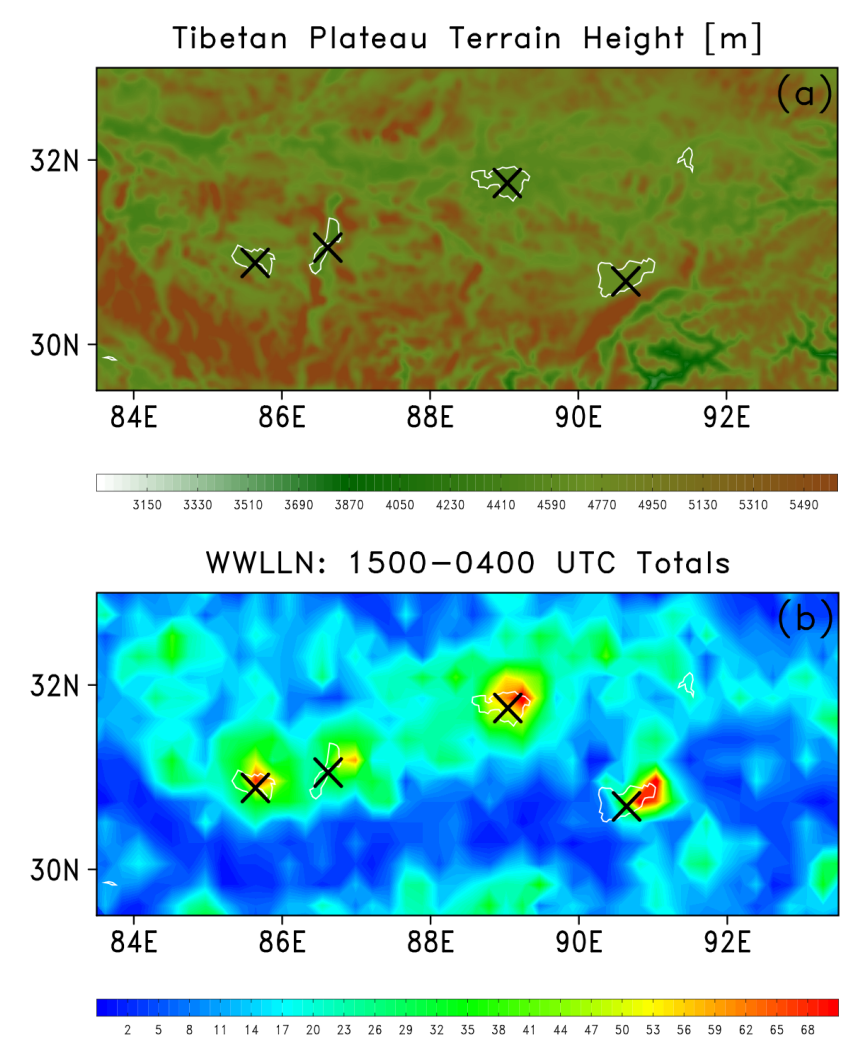

Fig. 13. (a) Terrain (m) of the Tibetan Plateau with black Xs denoting the locations of lakes. (b) Six year (2007-2012) WWLLN lightning totals for 15:00-04:00 UTC for August and September showing "hot spots" of lightning (deep convection) near the lakes (black Xs). The lightning data were binned into $25 \mathrm{~km} \times 25 \mathrm{~km}$ grid boxes.

respectively, were classified as convective. The trajectories revealed that more than $90 \%$ of the convective parcels comprising the ULAC came from either the Tibetan Plateau (TP) or southern slope (SS) regions. If we were to assume that the ULAC consists entirely of convectively lofted parcels, we could infer that all of these parcels might have been lofted just as rapidly. However, the $6 \mathrm{~h}$ cutoff on the back trajectories did not allow sufficient time to account for the horizontal transport occurring after convection. This suggests that the other regions (e.g., BOB and IND) might make a greater contribution to the composition of the ULAC than our results imply. However, quantifying the role of horizontal transport that occurs after convection goes beyond the scope of this study.

The results of our trajectory study were consistent with $\mathrm{Li}$ et al. (2005), Fu et al. (2006), and Wright et al. (2011). However, they were somewhat different from the findings of Park et al. (2007, 2009) and Chen et al. (2012), who argue that convection over the Bay of Bengal is more important than that over the Tibetan Plateau. Further analysis revealed a large diurnal cycle in the number of convective trajectories reaching the ULAC, with the greatest number occurring dur- ing the late afternoon and into the early night (16:00-23:00 LST). The observed timing of the convective trajectories was consistent with observational studies of convection over the TP and SS regions (e.g., Yaodong et al., 2008; Luo et al., 2010). The trajectories highlighted the importance of this everyday diurnal convection in transporting boundary layer air into the ULAC and pointed to the TP as the dominant region where this convection occurs.

A large increase in the number of convective trajectories occurred on 16 August 2012 (Fig. 8a). We produced WRF output at $15 \mathrm{~min}$ intervals to examine this day in detail. A forward-trajectory analysis was conducted using the high temporal resolution output. The results indicated that the weakest convection occurred over the Tibetan Plateau region, while the strongest was located over the southern slope (Table 1). However, parcels originating from the Tibetan Plateau reached the $150 \mathrm{hPa}$ surface more frequently than those originating over the other three regions. Because the elevation of the Tibetan Plateau is $\sim 3000-5000 \mathrm{~m}$, its convection does not have to be as deep to reach the $150 \mathrm{hPa}$ surface.

Vertical mass fluxes of water vapor were calculated to determine which regions transported the most moisture into the ULAC. At $150 \mathrm{hPa}$, the TP region contributed the most water vapor to the ULAC (Fig. 11b). At $100 \mathrm{hPa}$, the TP and SS regions transported similar amounts. Although convection is weakest over the TP, the warmer ambient environment at upper levels, leading to greater parcel saturation mixing ratios, might allow convection occurring there to transport more moisture into the ULAC. This added warmth is due to the elevated base of the Tibetan Plateau, which allows more outgoing longwave radiation to be absorbed at higher altitudes.

Although not a focus of our study, the elevated surface of the Tibetan Plateau also might enhance the "cirrus-lofting" mechanism proposed by Corti et al. (2006). Because more outgoing longwave radiation will reach the upper levels over the elevated TP, cirrus clouds over this region will absorb more energy, creating mesoscale regions of ascent. This mechanism might enhance troposphere-to-stratosphere transport over the Tibetan Plateau.

Results showed that convection over the Tibetan Plateau most frequently impacts the ULAC. Observed WWLLN lightning during the study period showed that the timing of lightning over the Tibetan Plateau agreed closely with the timing of the convective trajectories impacting the ULAC (Fig. 10), further supporting this finding. Close analysis of the WWLLN lightning climatology showed that Tibetan lakes might provide a mesoscale triggering mechanism to initiate convection in the region. The role of the Tibetan lakes in triggering convection that ultimately impacts the ULAC requires further study.

It should be noted that our results show only a physical and dynamical pathway for boundary layer air to enter the ULAC through the TP and SS regions. Quantifying the amount of pollution that each region transports would 
require detailed knowledge of source distributions and a coupled meteorological-chemical simulation with convectivepermitting grid spacing.

Although our results are based only on a 10-day period during the 2012 Asian summer monsoon, we hypothesize that they are representative of other periods of monsoon convection. However, because the ASM exhibits both interannual variability and intraseasonal oscillations, additional high-resolution simulations that span longer time periods will be needed to validate this hypothesis. Our results also highlight the importance of using convective-permitting grid spacing when performing modeling studies of convection, especially in the ASM region: using this resolution allowed us to isolate the effects of rapid transport due to deep convection and study its specific impacts on the ULAC.

Acknowledgements. This research was sponsored by the NASA Tropospheric Chemistry Program under Grant NNX0AH72G. Additional support was provided by NASA Headquarters under the NASA Earth and Space Science Fellowship Program - Grant NNX13AM09H. We appreciate the assistance of the FSU high-performance computing center and Robert Holzworth of the University of Washington, who provided the WWLLN data. We would like to thank Tristan Hall at Florida State University for providing the code to grid the WWLLN lightning data for our needs. The code is available online at http://fuelberg.met.fsu.edu/pub/thall/wwlln2grads/. Thanks are also given for the helpful comments and suggestions from the ACP editor, Cameron Homeyer, and the two anonymous reviewers.

Edited by: T. J. Dunkerton

\section{References}

Ávila, E. E., Bürgesser, R. E., Castellano, N. E., Collier, A. B., Compangnucci, R. H., and Hughes, A. R. W.: Correlations between deep convection and lightning activity on a global scale, J. Atmos. Sol-Terr. Phys., 72, 1114-1121, 2010.

Barros, A. P., Kim, G., Williams, E., and Nesbitt, S. W.: Probing orographic controls in the Himalayas during the monsoon using satellite imagery, Nat. Hazards Earth Syst. Sci., 4, 29-51, doi:10.5194/nhess-4-29-2004, 2004.

Bergman, J. W., Jensen, E. J., Pfister, L., and Yang, Q.: Seasonal differences of vertical transport efficiency in the tropical tropopause layer: On the interplay between deep convection, large-scale vertical ascent, and horizontal circulations, J. Geophys. Res., 114, D05302, doi:10.1029/2011JD016992, 2012.

Bergman, J. W., Fierli, F., Jensen, E. J., Honomichl, S., and Pan, L. L.: Boundary layer sources for the Asian anticyclone: Regional contributions to a vertical conduit, J. Geophys. Res., 118, 25602575, doi:10.1002/jgrd.50142, 2013.

Bonazzola, M. and Haynes, P. H.: A trajectory-based study of the tropical tropopause region, J. Geophys. Res., 109, D20112, doi:10.1029/2003JD004356, 2004.

Carrico, C. M., Bergin, M. H., Shrestha, A. B., Dibb, J. E., Gomes, L., and Harris, J. M.: The importance of carbon and mineral dust to seasonal aerosol properties in the Nepal Himalaya, Atmos. Environ., 37, 2811-2824, 2003.

Chen, B., Xu, X. D., Yang, S., and Zhao, T. L.: Climatological perspectives of air transport from atmospheric boundary layer to tropopause layer over Asian monsoon regions during boreal summer inferred from Lagrangian approach, Atmos. Chem. Phys., 12, 5827-5839, doi:10.5194/acp-12-5827-2012, 2012.

Chen, P.: Isentropic cross-tropopause mass exchange in the extratropics, J. Geophys. Res., 100, 16661-16673, 1995.

Chou, M., Suarez, M. J., Liang, X., and Yan, M. M. H.: A thermal infrared radiation parameterization for atmospheric studies, NASA Technical Report Series on Global Modeling and Data Assimilation NASA/TM-2001-104606, 68 pp., 2001.

Corti, T., Luo, B. P., Fu, Q., Vömel, H., and Peter, T.: The impact of cirrus clouds on tropical troposphere-to-stratosphere transport, Atmos. Chem. Phys., 6, 2539-2547, doi:10.5194/acp-6-25392006, 2006.

Corti, T., Luo, B. P., and Peter, T.: Mean radiative energy balance and vertical mass fluxes in the equatorial upper troposphere and lower stratosphere, Geophys. Res. Lett., 32, L06802, doi:10.1029/2004GL021889, 2005.

Deierling, W., and Peterson, W. A.: Total lightning activity as an indicator of updraft characteristics, J. Geophys. Res., 113, D16210, doi:10.1029/2007JD009598, 2008.

Dethof, A., O’Neill, A., Slingo, J. M., and Smit, H. G. J.: A mechanism for moistening the lower stratosphere involving the Asian summer monsoon, Q. J. Roy. Meteorol. Soc., 125, 1079-1106, 1999.

Done, J., C. and Weisman, M.: The next generation of NWP: Explicit forecasts of convection using the Weather Research and Forecasting (WRF) model, Atmos. Sci. Lett., 5 (6), 110-117, 2004.

Dowden, R. L., Brundell, J. B., and Rodger, C. J.: VLF lightning location by time of group arrival (TOGA) at multiple sites, J. Atmos. Sol-Terr Phys., 64, 817-830, 2002.

Draxler, R. R.: Boundary layer isentropic and kinematic trajectories during the August 1993 North Atlantic Regional Experiment Intensive, J. Geophys. Res., 101, 29255-29268, 1996.

Draxler, R. R. and Hess, G. D.: An overview of the HYSPLIT_4 modeling system of trajectories, dispersion, and deposition, Aust. Meteor. Mag., 47, 295-308, 1998.

Draxler, R. R. and Hess, G. D.: Description of the hysplit4 modeling system, NOAA Tech. Rep. ERL ARL-224, 27 pp., NTIS PB297398, 2010.

Duan, A. M. and Wu, G. X.: Role of the Tibetan Plateau thermal forcing in the summer climate patterns over subtropical Asia, Clim Dynam., 24, 793-807, 2005.

Dunkerton, T. J.: Evidence of meridional motion in the summer lower stratosphere adjacent to monsoon regions, J. Geophys. Res., 100, 16675-16688, 1995.

Ek, M. B., Mitchell, K. E., Lin, Y., Rogers, E., Grunmann, P., Koren, V., Gayno, G., and Tarpley, J. D.: Implementation of Noah land surface model advances in the National Centers for Environmental Prediction operational mesoscale Eta model, J. Geophys. Res., 108, 8851, doi:10.1029/2002JD003296, 2003.

Emmons, L. K., Walters, S., Hess, P. G., Lamarque, J.-F., Pfister, G. G., Fillmore, D., Granier, C., Guenther, A., Kinnison, D., Laepple, T., Orlando, J., Tie, X., Tyndall, G., Wiedinmyer, C., Baughcum, S. L., and Kloster, S.: Description and evaluation of 
the Model for Ozone and Related chemical Tracers, version 4 (MOZART-4), Geosci. Model Dev., 3, 43-67, doi:10.5194/gmd3-43-2010, 2010.

Fu, R., Hu, Y., Wright, J. S., Jiang, J. H., Dickinson, R. E., Chen, M., Filipiak, M., Read, W. G., Waters, J. W., and $\mathrm{Wu}, \mathrm{D}$. L.: Short circuit of water vapor and polluted air to the global stratosphere by convective transport over the Tibetan Plateau, Proc. Natl. Acad. Sci. USA, 103, 5664-5669, doi:10.1073/pnas.0601584103, 2006.

Fueglistaler, S., Dessler, A. E., Dunkerton, T. J., Folkins, I., Fu, Q., and Mote, P. W.: Tropical tropopause layer, Rev. Geophys., 47, 1-31, 2009.

Fueglistaler, S., Wernli, H., and Peter, T.: Tropical troposphereto-stratosphere transport inferred from trajectory calculations, J. Geophys. Res., 109, D03108, doi:10.1029/2003JD004069, 2004.

Gauss, M., Myhre, G., Isaksen, I. S. A., Grewe, V., Pitari, G., Wild, O., Collins, W. J., Dentener, F. J., Ellingsen, K., Gohar, L. K., Hauglustaine, D. A., Iachetti, D., Lamarque, J.-F., Mancini, E., Mickley, L. J., Prather, M. J., Pyle, J. A., Sanderson, M. G., Shine, K. P., Stevenson, D. S., Sudo, K., Szopa, S., and Zeng, G.: Radiative forcing since preindustrial times due to ozone change in the troposphere and the lower stratosphere, Atmos. Chem. Phys., 6, 575-599, doi:10.5194/acp-6-575-2006, 2006.

Gettelman, A. and de F. Forster, P. M.: A climatology of the tropical tropopause layer, J. Meteor. Soc. Jpn., 80, 911-924, 2002.

Gettelman, A., Kinnison, D. E., Dunkerton, T. J., and Brasseur, G. P.: Impact of monsoon circulations on the upper troposphere and lower stratosphere, J. Geophys. Res., 109, D22101, doi:10.1029/2004JD004878, 2004.

Gettelman, A. and Fu, Q.: Observed and simulated uppertropospheric water vapor feedback, J. Clim., 21, 3282-3289, 2007.

Grell, G. A. and Devenyi, D.: A generalized approach to parameterizing convection combining ensemble and data assimilation techniques, Geophys. Res. Lett., 29, 1693, doi:10.1029/2002GL015311, 2002.

Halland, J. J., Fuelberg, H. E., Pickering, K. E., and Luo, M.: Identifying convective transport of carbon monoxide by comparing remotely sensed observations from TES with cloud modeling simulations, Atmos. Chem. Phys., 9, 4279-4294, 2009, http://www.atmos-chem-phys.net/9/4279/2009/.

Held, I. M. and Soden, B. J.: Water vapor feedback and global warming, Annu. Rev. Energy. Environ., 25, 441-475, 2000.

Hirose, M. and Nakamura, K.: Spatial and diurnal variation of precipitation systems over Asia observed by the TRMM Precipitation Radar, J. Geophys. Res., 110, D05106, doi:10.1029/2004JD004815, 2005.

Hoskins, B. J. and Rodwell, M. J.: A model of the Asian summer monsoon. Part I: The global scale, J. Atmos. Sci., 52, 1329-1340, 1995.

Hong, S. -Y., Noh, Y., and Dudhia, J.: A new vertical diffusion package with explicit treatment of entrainment processes, Mon. Weather Rev., 134, 2318-2341, 2006.

Houze, R. A., Wilton, D. C., and Smull, B. F.: Monsoon convection in the Himalayan region as seen by the TRMM precipitation radar, Q. J. Roy. Meteorol. Soc., 133, 1389-1411, 2007.

Jacob, D. J.: Introduction to Atmospheric Chemistry. Princeton University Press, 266 pp., 1999.
James, R., Bonazzola, M., Legras, B., Surbled, K., and Fueglistaler, S.: Water vapor transport and dehydration above convective outflow during Asian monsoon, Geophys. Res. Lett., 35, L20810, doi:10.1029/2008GL035441, 2008.

Jiang, J. H., Livesey, N. J., Su, H., Neary, L., McConnell, J. C., and Richards, N. A. D.: Connecting surface emissions, convective uplifting, and long-range transport of carbon monoxide in the upper troposphere: New observations from the Aura Microwave Limb Sounder, Geophys. Res. Lett., 34, L18812, doi:10.1029/2007GL030638, 2007.

Kain, J. S.: The Kain-Fritsch Convective Parameterization: An Update, J. Appl. Meteor., 43, 170-181. doi:10.1175/15200450(2004)043<0170:TKCPAU>2.0.CO;2, 2004.

Kain, J. S., Weiss, S. J., Bright, D. R., Baldwin, M. E., Levit, J. J., Carbin, G. W., Schwartz, C. S., Weisman, M. L., Droegemeier, K. K., Weber, D. B., and Thomas, K. W.: Some practical considerations regarding horizontal resolution in the first generation of operational convection-allowing NWP, Weather Forecast., 23, 931-952, 2008.

Klich, C. A. and Fuelberg, H. E.: The role of horizontal model resolution in assessing the transport of $\mathrm{CO}$ in a middle latitude cyclone using WRF-Chem, Atmos. Chem. Phys., 14, 609-627, doi:10.5194/acp-14-609-2014, 2014.

Krishnamurti, T. N., Daggupaty, S. M., Fain, J., Kamitsu, M., and Lee, J. D.: Tibetan high and upper tropospheric tropical circulations during northern summer, B. Am. Meteor. Soc., 54, 12341249, 1973.

Kurosaki, Y. and Kimura, F.: Relationship between topography and daytime cloud activity around Tibetan Plateau, J. Meteor. Soc. Jpn., 80, 1339-1355, 2002.

Lackmann, G. M.: Midlatitude Synoptic Meteorology: Dynamics, Analysis, and Forecasting, Am. Meteor. Soc., ISBN 978-1878220-10-3, 345 pp., 2011.

Lelieveld, J., Brühl, C., Jöckel, P., Steil, B., Crutzen, P. J., Fischer, H., Giorgetta, M. A., Hoor, P., Lawrence, M. G., Sausen, R., and Tost, H.: Stratospheric dryness: model simulations and satellite observations, Atmos. Chem. Phys., 7, 1313-1332, doi:10.5194/acp-7-1313-2007, 2007.

Li, Q., Jiang, J. H., Wu, D. L., Read, W. G., Livesey, N. J., Jacob, D. J.: Convective outow of south asian pollution: A global ctm simulation compared with EOS MLS observations, Geophys. Res. Lett., 32, L14826, doi:10.1029/2005GL022762, 2005.

Liping, L., Jinming, F., Rongzhong, C., Yunjun, Z., and Ueno, K.: The diurnal variation of precipitation in monsoon season in the Tibetan Plateau, Adv. Atmos. Sci., 19, 365-378, 2002.

Luo, Y., Zhang, R., Qian, W., and Luo, Z.: Inter-comparison of deep convection over the Tibetan Plateau-Asian Monsoon Region and subtropical North America in boreal summer using CloudSat/CALIPSO data, J. Clim., 24, 2164-2177, 2010.

Madronich, S.: Photodissociation in the atmosphere. I - Actinic flux and the effects of ground reflections and clouds, J. Geophys. Res., 92, 9740-9752, doi:10.1029/JD092iD08p09740, 1987.

Markowski, P. and Richardson, Y.: Mesoscale Meteorology in Midlatitudes, Wiley-Blackwell, 407 pp., 2010.

Medina, S., Houze, R. A., Kumar, A., and Niyogi, D.: Summer monsoon convection in the Himalayan region: Terrain and land cover effects, Q. J. Roy. Meteorol. Soc., 136, 593-616, 2010.

Mlawler, E. J., Taubman, S. J., Brown, P. D., Iacono, M. J., and Clough, S. A.: Radiative transfer for inhomogeneous atmo- 
sphere: RRTM, a validated correlated-k model for the longwave, J. Geophys. Res., 102, 16663-16682, 1997.

Murakami, M.: Analysis of the deep convective activity over the western Pacific and Southeast Asia. Part I: Diurnal variation, J. Meteor. Soc. Jpn., 61, 60-76, 1983.

Niziol, T. A., Snyder, W. R., and Waldstreicher, J. S.: Winter weather forecasting throughout the eastern United States. Part IV: lake effect snow, Weather Forecast., 10, 61-77, 1995.

Park, M., Randel, W. J., Emmons, L. K., Bernath, P. F., Walker, K. A., and Boone, C. D.: Chemical isolation in the Asian summer monsoon anticyclone observed in atmospheric chemistry experiment (ACE-FTS) data, Atmos. Chem. Phys., 8, 757-764, doi:10.5194/acp-8-757-2008, 2008.

Park, M., Randel, W. J., Emmons, L. K., and Livesey, N. J.: Transport pathways of carbon monoxide in the Asian summer monsoon diagnosed from model of ozone and related tracers (MOZART), J. Geophys. Res., 114, D08303, doi:10.1029/2008JD010621, 2009.

Park, M., Randel, W. J., Gettelman, A., Massie, S. T., and Jiang, J. H.: Transport above the Asian summer monsoon anticyclone inferred from aura microwave limb sounder tracers, J. Geophys. Res., 112, D16309, doi:10.1029/2006JD008294, 2007.

Petch, J. C., Brown, A. R., and Gray, M. E. B.: The impact of horizontal resolution on the simulations of convective development over land, Q. J. Roy. Meteor. Soc., 128, 2031-2044, 2002.

Randel, W. J. and Park, M.: Deep convective influence on the Asian summer monsoon anticyclone and associated tracer variability observed with Atmospheric Infrared Sounder (AIRS), J. Geophys. Res., 111, D12314, doi:10.1029/2005JD006490, 2006.

Randel, W. J., Park, M., Emmons, L., Kinnison, D., Bernath, P., Walker, K. A., Boone, C., and Pumphrey, H.: Asian monsoon transport of pollution to the stratosphere, Science, 328, 611-613, 2010.

Rienecker, M. M., Suarez, M. J., Gelaro, R., Todling, R., Bacmeister, J., Liu, E., Bosilovich, M. G., Schubert, S. D., Takacs, L., Kim, G.-K., Bloom, S., Chen, J., Collins, D., Conaty, A., da Silva, A., Gu, W., Joiner, J., Koster, R. D., Lucchesi, R., Molod, A., Owens, T., Pawson, S., Pegion, P., Redder, C. R., Reichle, R., Robertson, F. R., Ruddick, A. G., Sienkiewicz, M., and Woollen, J.: MERRA: NASA's Modern-Era Retrospective Analysis for Research and Applications, J. Clim., 24, 3624-3648, 2011.

Rodger, C. J., Brundell, J. B., Holzworth, R. H., and Lay, E. H.: Growing detection efficiency of the World Wide Lightning Location Network, Proc. AIP. Conf. on Coupling of Thunderstorms and Lightning Discharges to Near-Earth, 1118, Corte, France, 15-20, 2009.

Romatschke, U., Medina, S., and Houze, R. A.: Regional, seasonal, and diurnal variations of extreme convection in the South Asian region, J. Clim., 23, 419-439, 2010.
Skamarock, W. C., Klemp, J. B., Dudhia, J., Gill, D. O., Barker, D. M., Duda, M. G., Huang, X.-Y., Wang, W., and Powers, J. G.: Description of the Advanced Research WRFV3, NCAR Tech. Note, 2008.

Stenke, A., and Grewe, V.: Simulation of stratospheric water vapor trends: impact on stratospheric ozone chemistry, Atmos. Chem. Phys., 5, 1257-1272, doi:10.5194/acp-5-1257-2005, 2005.

Taylor, Z. B.: The impact of cumulus parameterization schemes on the convective transport of biomass burning emissions using WRF-CHEM, M. S. Thesis, The Florida State University, 76 pp., 2011.

Thompson, G., Field, P. R., Rasmussen, R. M., and Hall, W. D.: Explicit Forecasts of Winter Precipitation Using an Improved Bulk Microphysics Scheme. Part II: Implementation of a New Snow Parameterization, Mon. Weather Rev., 136, 5095, doi:10.1175/2008MWR2387.1, 2008.

Tzella, A. and Legras, B.: A Lagrangian view of convective sources for transport across the tropical tropopause layer: distribution, times and the radiative influence of clouds, Atmos. Chem. Phys., 11, doi:10.5194/acp-11-12517-2011, 2011.

Weisman, M. L., Davis, C., Wang, W., Manning, K. W., and Klemp, J. B.: Experiences with 0-36-h explicit convective forecasts with the WRF-ARW model, Weather Forecast., 23, 407-437, 2008.

Wright, J. S., Fu, R., Fueglistaler, S., Liu, Y. S., and Zhang, Y.: The influence of summertime convection over Southeast Asia on water vapor in the tropical stratosphere, J. Geophys. Res., 116, D12302, doi:10.1029/2010JD015416, 2011.

Wu, G. X., Li, W., Guo, H., Liu, H., Xue, J., and Wang, Z.: Sensible heat driven air-pump over the Tibetan Plateau and its impacts on the Asian summer monsoon, Chinese. Sci. Press., 116-126, 1997.

Wu, G., Liu, Y., He, B., Bao, Q., Duan, A., and Jin, F.: Thermal controls on the Asian summer monsoon, Sci. Rep., 2, 404, doi:10.1038/srep00404, 2012.

Yaodong, L., Yun, W., Yang, S., Liang, H., Shouting, G., and Fu, R.: Characteristics of summer convective systems initiated over the Tibetan Plateau. Part I: origin, track, development, and precipitation, J. Appl. Meteor. Clim., 47, 2679-2695, 2008.

Zhang, Q., Streets, D. G., Carmichael, G. R., He, K. B., Huo, H., Kannari, A., Klimont, A., Park, I. S., Reddy, S., Fu, J. S., Chen, D., Duan, L., Lei, Y., Wang, L. T., and Yao, Z. L.: Asian emissions in 2006 for the NASA INTEX-B mission, Atmos. Chem. Phys., 9, 5131-5153, doi:10.5194/acp-9-5131-2009, 2009. 